Article

\title{
Evaluation of Antioxidant and Enzyme Inhibition Properties of Croton hirtus L'Hér. Extracts Obtained with Different Solvents
}

\author{
Stefano Dall'Acqua 1,*(D), Kouadio Ibrahime Sinan ${ }^{2}$, Stefania Sut ${ }^{1}$, Irene Ferrarese ${ }^{1}$, Ouattara Katinan Etienne ${ }^{3}$, \\ Mohamad Fawzi Mahomoodally ${ }^{4, *}$, Devina Lobine ${ }^{4}$ and Gokhan Zengin ${ }^{2} \mathbb{D}$
}

1 Department of Pharmaceutical and Pharmacological Sciences, University of Padova, Via Marzolo 5, 35131 Padova, Italy; stefania_sut@hotmail.it (S.S.); irene.ferrarese@unipd.it (I.F.)

2 Department of Biology, Science Faculty, Selcuk University, Campus, 42130 Konya, Turkey; sinankouadio@gmail.com (K.I.S.); gokhanzengin@selcuk.edu.tr (G.Z.)

3 Laboratoire de Botanique, UFR Biosciences, Université Félix Houphouët-Boigny, 00225 Abidjan, Côte d'Ivoire; katinan.etienne@gmail.com

4 Department of Health Sciences, Faculty of Medicine and Health Sciences, University of Mauritius, 230 Réduit, Mauritius; devinalobine@gmail.com

* Correspondence: stefano.dallacqua@unipd.it (S.D.); f.mahomoodally@uom.ac.mu (M.F.M.)

check for updates

Citation: Dall'Acqua, S.; Sinan, K.I.; Sut, S.; Ferrarese, I.; Etienne, O.K. Mahomoodally, M.F.; Lobine, D.; Zengin, G. Evaluation of Antioxidant and Enzyme Inhibition Properties of Croton hirtus L'Hér. Extracts Obtained with Different Solvents. Molecules 2021, 26, 1902. https://doi.org/ $10.3390 /$ molecules 26071902

Academic Editors: Simona Fabroni, Krystian Marszałek and Aldo Todaro

Received: 27 February 2021

Accepted: 25 March 2021

Published: 28 March 2021

Publisher's Note: MDPI stays neutral with regard to jurisdictional claims in published maps and institutional affiliations.

Copyright: (c) 2021 by the authors. Licensee MDPI, Basel, Switzerland. This article is an open access article distributed under the terms and conditions of the Creative Commons Attribution (CC BY) license (https:// creativecommons.org/licenses/by/ $4.0 /)$.

\begin{abstract}
Croton hirtus L'Hér methanol extract was studied by NMR and two different LC-DAD-MS using electrospray (ESI) and atmospheric pressure chemical ionization (APCI) sources to obtain a quali-quantitative fingerprint. Forty different phytochemicals were identified, and twenty of them were quantified, whereas the main constituents were dihydro $\alpha$ ionol- $O$-[arabinosil(1-6) glucoside] (133 mg/g), dihydro $\beta$ ionol-O-[arabinosil(1-6) glucoside] $(80 \mathrm{mg} / \mathrm{g}), \beta$-sitosterol $(49 \mathrm{mg} / \mathrm{g})$, and isorhamnetin-3-O-rutinoside $(26 \mathrm{mg} / \mathrm{g})$. C. hirtus was extracted with different solvents-namely, water, methanol, dichloromethane, and ethyl acetate - and the extracts were assayed using different in vitro tests. The methanolic extracts presented the highest 1,1-diphenyl-2-picrylhydrazyl (DPPH), 2,2'-azino-bis(3-ethylbenzothiazoline)-6-sulfonic acid (ABTS), and ferric reducing antioxidant power (FRAP) values. All the tested extracts exhibited inhibitory effects on acetylcholinesterase (AChE) and butyrylcholinesterase (BChE), with a higher activity observed for dichloromethane (AChE: 5.03 and BChE: $16.41 \mathrm{mgGALAE} / \mathrm{g}$ ), while the methanolic extract showed highest impact against tyrosinase (49.83 mgKAE/g). Taken together, these findings suggest $C$. hirtus as a novel source of bioactive phytochemicals with potential for commercial development.
\end{abstract}

Keywords: Croton hirtus; enzyme; flavonoid glycosides; bioactive agents

\section{Introduction}

The genus, Croton (Euphorbiaceae) comprises of about 1300 species, mostly widespread in tropical and subtropical regions of both hemispheres [1]. Several members of the genus are popular in folk medicine as they are commonly used against a range of illnesses such as inflammatory conditions, pain, diabetes, hypertension, malaria, gastrointestinal disturbances, and ulcers, amongst others [1-3]. Croton cajucara Benth., C. celtidifolius Baill., C. eluteria Bennett, C. zambesicus Müll. Arg., and C. macrostachys Hochst. ex Rich are some of the Croton species used for medicinal purposes. The chemistry of the genus is considerably diverse. Diterpenoids such as phorbol esters, clerodane, neoclerodane, isopimarane, kaurane, and labdane type terpenoids are the principal bioactive components in the genus. Some Croton species are also rich in alkaloids such as taspine and julocrotol $[1,4]$.

Croton hirtus L'Hér., also known as C. glandulosus, is an erect shrub, and various studies have investigated the chemical composition of its essential oil, leaves, and roots. In particular, Daouda et al. [2] have reported the antimicrobial action of C. hirtus essential oil, which was found to contain $93.49 \%$ of terpene derivatives, with $15.55 \%$ monoterpenes and $77.94 \%$ sesquiterpenes. In a study by de Lima, Medeiros, Cunha, da Silva, de Andrade, Neto, Lopes, 
Steffen, Araújo, and Reis [3], the presence of spathulenol (26.7\%), E-caryophyllene (10.0\%), bicyclogermacrene $(9.5 \%), \alpha$-cadinol (7.7\%), and cubenol (7.0\%) as main constituents of the essential oils extracted from C. hirtus leaves was reported. In 2019, Rosandy, Azman, Khalid, Othaman, Lazim, Choudary, Syah, Latip, Said, and Bakar [4] identified two new diterpenoids from the roots of $C$. hirtus. Preliminary reports suggested the presence of alkaloid, anthraquinone, flavonoid, steroids, and terpenoid in different parts of $C$. hirtus $[5,6]$. However, as literature shows, information available related to the phytoconstituents of the plant are punctual, and a complete accurate study of C. hirtus leaves composition is still missing. Moreover, there is a scarcity of information in literature on pharmacological properties of C. hirtus. In a recent paper, Kim et al. [7] reported the anti-inflammatory effects of $C$. hirtus via inhibition of nuclear factor kappa-light-chain-enhancer of activated $B$ cells (NF- $\kappa B$ ) signaling pathway.

In this study, detailed phytochemical fingerprinting of $C$. hirtus was obtained using NMR analysis of the methanol extract and LC-DAD-MS ${ }^{\mathrm{n}}$ methods, one using electrospray ionization (ESI) and one using atmospheric pressure chemical ionization (APCI) ion sources.

Once establishing the chemical composition to assess biological activities, plant material was extracted with different solvents-namely, water, methanol, dichloromethane, and ethyl acetate - and the obtained extracts were subjected to different in vitro bioassays. Free radical scavenging, reducing power, metal chelating, and phosphomolybdenum assays were employed for evaluating antioxidant effects of the different extracts, while the enzyme inhibitory activity against targeted enzymes such as cholinesterases, tyrosinase, $\alpha$-amylase, and $\alpha$-glucosidase-involved in significant human diseases-were determined. As a general measurement of the content of extracted constituents, the phenolics content of C. hirtus were determined by spectrophotometrical assays.

\section{Results and Discussion}

\subsection{Phytochemical Analysis}

C. hirtus methanol extract was subjected to different NMR experiments as heteronuclear single quantum coherence (HSQC) and heteronuclear multiple bond correlation (HMBC) as well as correlation spectroscopy (COSY). Based on the chemical shifts of ${ }^{1} \mathrm{H}$ and ${ }^{13} \mathrm{C}$ and the correlations in the $2 \mathrm{D}$ spectra, some tentative assignments were obtained and are summarized in Table 1. The presence of simple phenolics such as protocatechuic acid were tentatively established due to the presence of spin system relating to aromatic signals observed in COSY, suggesting the presence of 1,3,4 tri-substituted ring, as well as on the basis of the chemical shift of carbons (obtained from the HSQC) and the long-range correlation with carboxyl function (Table 1; Figure 1). Further signals can be ascribed to hydroxycinnamic acid derivatives due to the olefinic signals at $\delta 7.59$ and 6.45 , as well as due to HMBC correlations with aromatic positions. Signals suggesting the presence of flavonoid derivatives can be also observed-namely, the H-6 and H-8 position of flavonols as well as signals ascribable to ring A and B (Table 1; Figure 1). Additionally, different signals support the presence of sugar and glycosidic derivatives. In the 1D and 2D NMR spectrum, some signals are ascribable to megastigmane derivative (Table 1), which is consistent with the literature [8]. In particular, the diagnostic signals are the geminal methyl groups that are partially overlapped with other aliphatic signals in the extract and the sp ${ }^{2}$ olefinic protons of the HSQC-DEPT spectrum. Compounds structures were proposed as icariside B and corchionoside C (Figure 2), and an enlargement of the HSQC is reported with some key signals highlighted. Unsaturated proton signals of the $\alpha$ ionol derivative include the one at $\delta 5.25\left(\delta_{C} 126.2\right)$ that shows HMBC correlations with carbon signals at $\delta_{\mathrm{C}} 51.0\left(\mathrm{CH}\right.$ in the six membered rings linked to the side chain), at $\delta_{\mathrm{C}} 36.0\left(\mathrm{CH}_{2}\right)$, and at $\delta_{C} 135.1$ (the quaternary carbon signal). From the methyl group at $\delta 2.05$, correlations are observed with the carbon at $\delta 135.1$ and with 126.5 . Secondary methyl group at $\delta 1.14$ can be assigned to the methyl group nearby the glycosidic linkage due to the HMBC with carbon at $\delta$ 73.1. These data and the signals largely observed in the sugar region supported the MS identification of compound dehydro $\alpha$ ionol-O-[arabinosil(1-6) glucoside]. Diagnostic 
signals for the isomer dehydro $\beta$ ionol-O-[arabinosil(1-6) glucoside] are the $\mathrm{CH}$ sp2 and by the $\mathrm{HMBC}$ with the $\mathrm{CH}$ at $\delta 72$ and the secondary methyl group.

Table 1. NMR data obtained from 1D and 2D NMR experiments and assignments of constituents identified in Croton hirtus extract. COSY, correlation spectroscopy.

\begin{tabular}{|c|c|c|c|c|}
\hline $\begin{array}{l}\text { Compound } \\
\text { No. }\end{array}$ & $\begin{array}{c}\text { Compounds or Class of Compounds } \\
\text { Atom Position }\end{array}$ & $\delta \mathbf{H}$ & $\delta \mathrm{c}$ & Correlations in $\mathrm{HMBC}$ or COSY \\
\hline & Protocatechuic acid (HMDB0001856) & & & \\
\hline \multirow[t]{40}{*}{1} & 2 & 7.53 & 115 & 167.0 (HMBC); 7.48 (COSY) \\
\hline & 5 & 6.90 & 115.4 & $7.48(\mathrm{COSY})$ \\
\hline & 6 & 7.48 & 124.7 & 167.0 (HMBC) 7.53; 6.90 (COSY) \\
\hline & Caffeic acid moieties & & & \\
\hline & 7 & 7.59 & 143.9 & 167.5; 130.0 (HMBC); 6.45 (COSY) \\
\hline & 8 & 6.45 & 115.6 & $127.4 ; 7.59(\mathrm{COSY})$ \\
\hline & Aromatic ring protons & $7.14-6.80$ & $127.5,122.3$ & $145.3,151.0 ; 127.0,145 ; 114$ \\
\hline & Flavonoids & & & \\
\hline & H 6-8 of glycosidic flavonols & $6.10-6.22$ & 98.5-99.7 & 165-15599 101 (HMBC) \\
\hline & Ring B quercetin & $7.40-6-23$ & $\begin{array}{c}115.0,129,125 \\
118\end{array}$ & $150.0,145.3,131.0(\mathrm{HMBC})$ \\
\hline & Ring B kaempferol (HMDB0005801) & 7.98 & 130.5 & 165.0, 130.5 (HMBC); 6.80 (COSY) \\
\hline & & 6.80 & 115.0 & $115 ; 7.98(\mathrm{COSY})$ \\
\hline & $\begin{array}{l}\text { Sugar linked to phenolic portions } \\
\text { (Flavonol-O-glycosides or } \\
\text { hydroxycinnamic esters) }\end{array}$ & & & \\
\hline & Anomeric positions & 4.85 & 109.5 & \\
\hline & & 4.67 & 99.8 & $\begin{array}{c}\text { 165.0-160 (HMBC with position } 7 \\
\text { of flavonol moieties); } 3.30-3.40 \\
\text { (COSY) }\end{array}$ \\
\hline & & $4.43-4.50$ & 101.7 & $\begin{array}{l}133.8 \text { (HMBC with position } 3 \text { of } \\
\text { flavonol moieties); } 3.18 \text { (COSY) }\end{array}$ \\
\hline & & 4.22 & 104.7 & $3.18-3.28(\mathrm{COSY})$ \\
\hline & & 5.42 & 103 & 133.5 (HMBC position 3 flavonol) \\
\hline & Anomeric positions & & & \\
\hline & H-1 (rhamnose) & $4.60 \mathrm{brs}$ & 99.7 & 3.18 (COSY) \\
\hline & H-1 (hexose or pentose) & $4.50-4.70 \mathrm{~d}$ & 100.0-101.1 & $3.16,3.23$ (COSY) \\
\hline & H-1 (hexose or pentose) & $4.50-4.70$ & 100.0-101.1 & $3.16,3.23$ (COSY) \\
\hline & H-6 (hexose) free position & $3.30-3.50$ & 60.5 & \\
\hline & H-6 (hexose) glycosidic linked & $3.30-3.50$ & 64.5 & \\
\hline & $\begin{array}{l}\mathrm{CH} \text { bearing ester linkage (from sugar } \\
\text { residue) }\end{array}$ & 4.95 & 73.4 & $165,104,71$ \\
\hline & $\begin{array}{l}\mathrm{CH} \text { bearing ester linkage (from sugar } \\
\text { residue) }\end{array}$ & 5.08 & 71.2 & $165,89,63$ \\
\hline & Megastigmane (aglycone part) & & & \\
\hline & H-2 Icariside B & $5.85-5.90$ & 128.7 & 200, (HMBC) \\
\hline & $\mathrm{CH}_{2}-6$ Icariside $\mathrm{B}$ & 2.58 & 54.0 & $200,72.0(\mathrm{HMBC})$ \\
\hline & $\mathrm{CH}_{3}$ Icariside B & 1.02 & 24.2 & 77 (HMBC) \\
\hline & H-7 Corchionoside & 5.75 & 125.7 & \\
\hline & H-8 Corchionoside & 5.86 & 131.9 & \\
\hline & $\mathrm{CH} 3$ Corchioside & 1.21 & 19.6 & 73.0, 125.7 (HMBC) \\
\hline & dehydro Ionol derivatives & & & \\
\hline & $\mathrm{H} 3$ & $5.30,5.2$ & 127.5 & 141, 59, 36 (HMBC) \\
\hline & $\mathrm{CH}_{3}$ linked to double bond & 2.02 & 20.5 & 141,127 \\
\hline & $\begin{array}{l}\text { Geminal methyl groups, secondary } \\
\text { methyl group of the butanol chain } \\
\text { Fatty acid derivatives }\end{array}$ & $0.95-1.04$ & $23.9-24.1$ & 36.051 .072 .0 \\
\hline & terminal methyl groups & 0.93 & 17.5 & $40.0,23.0$ \\
\hline & $\mathrm{CH} 2$ & 2.02 & 19.5 & $24.2,30.0$ \\
\hline & $\mathrm{sp} 2$ & $5.35-5.40$ & 122.5 & \\
\hline
\end{tabular}



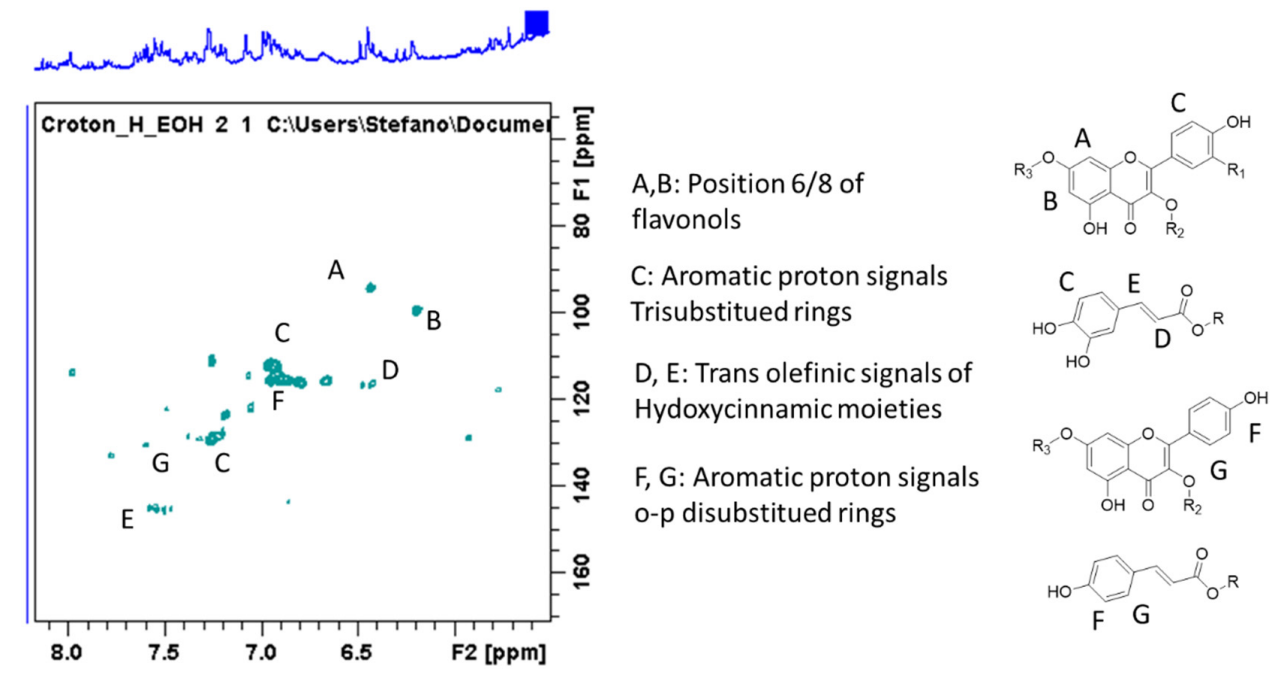

Figure 1. Heteronuclear single quantum coherence- Distortionless enhancement by polarization transfer, (HSCQ-DEPT) portion of the spectrum showing the signals ascribable to phenolic derivatives.

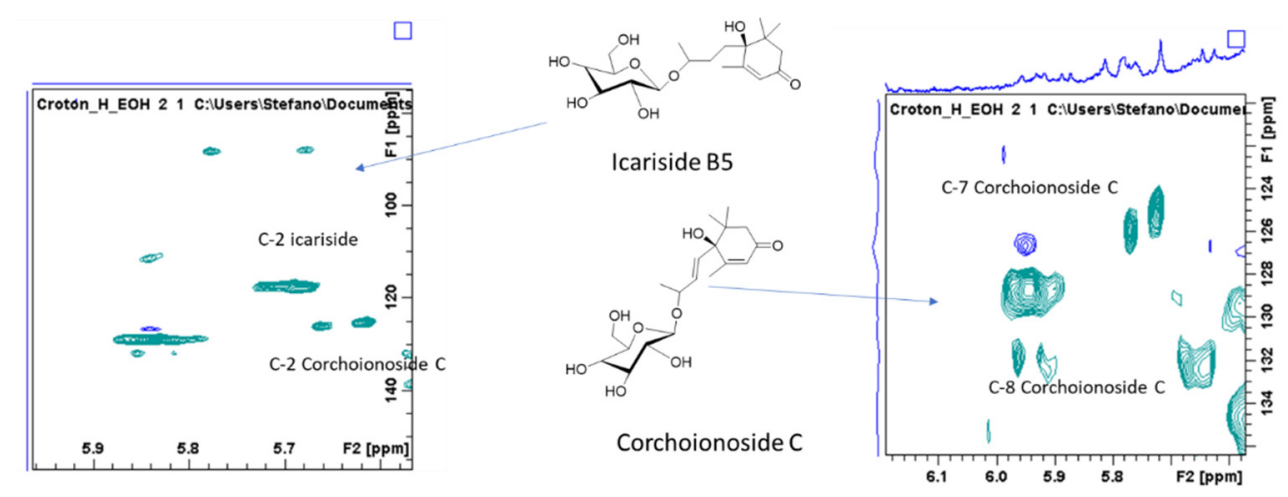

Figure 2. HSQC-DEPT portion of spectrum showing some of the diagnostic signals used to confirm structure identification.

A diffusion order spectroscopy experiment (DOSY) was also performed to observe different behavior of the various extracted phytochemicals present in the mixture. As shown in Figure 3, the spectrum has a group of signals that can be distinguished on the basis of their diffusion coefficients. Ethanol presents its signals largely separated from the other belonging to the plant constituents. The red line indicates the diffusion coefficient of dihydro ionol derivatives, the yellow one shows group of signals that can be ascribed to fatty acid derivatives, while hydroxycinnamic/phenylethanol compounds as well as flavonoid glycosides present larger values of diffusion coefficients.

To have detailed quali-quantitative fingerprint, liquid chromatography coupled with diode array detector and mass spectrometry (LC-DAD-MS ${ }^{n}$ ) methods were developed, and to detect a larger number of the different constituents present in the plant, electrospray (ESI) and atmospheric pressure chemical ionization (APCI) ion sources were used. Phytoconstituents were studied based on MS fragmentation and on the UV spectra (for the phenolic compounds). An exemplificative chromatogram is reported in Figure 4. 


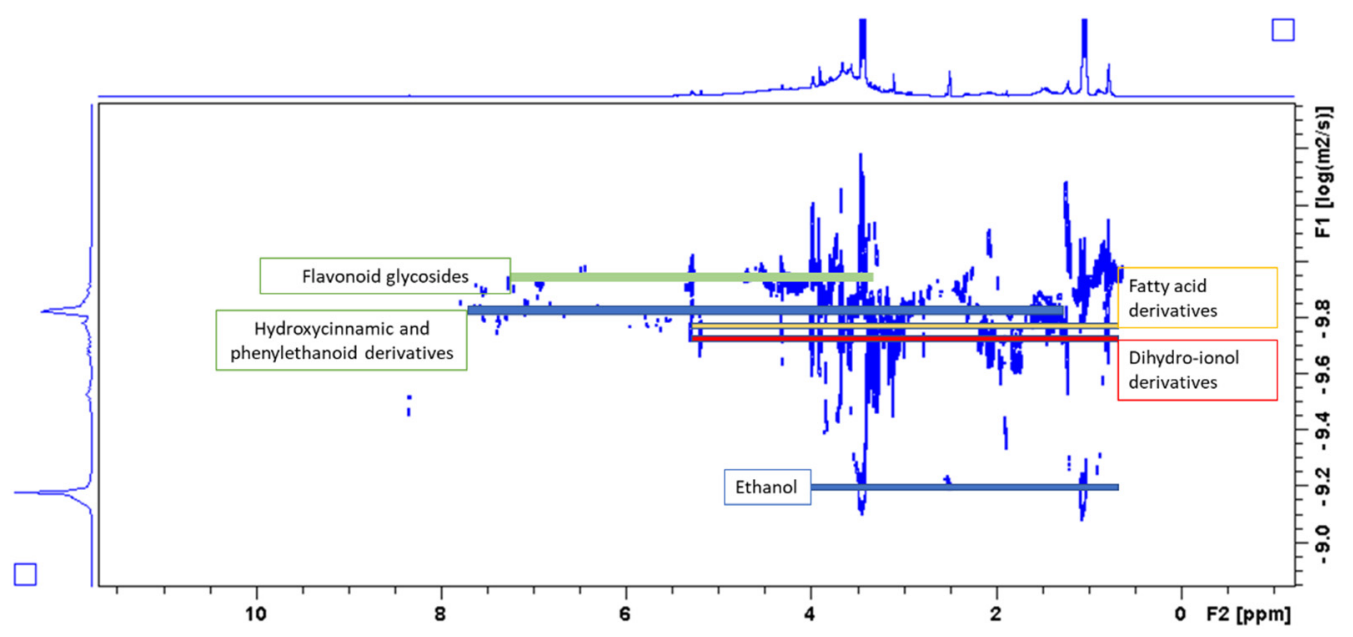

Figure 3. Diffusion order spectroscopy (DOSY) spectrum showing some of the different classes of constituents present in the C. hirtus extract.

Table 2. Identification and quantification of compounds in methanolic extract of Croton hirtus. * compared with authentic standard.

\begin{tabular}{|c|c|c|c|c|c|c|}
\hline $\begin{array}{c}\text { Compound } \\
\text { No. }\end{array}$ & $\begin{array}{l}\text { Retention } \\
\text { Time }\end{array}$ & {$[\mathbf{M}-\mathbf{H}]^{-}$} & Fragments & Formula & $\begin{array}{l}\text { Identification and } \\
\text { Reference }\end{array}$ & $\mathrm{mg} / \mathrm{g}$ \\
\hline \multicolumn{7}{|c|}{ Flavonoid glycosides } \\
\hline 1 & 16.5 & 755 & $\begin{array}{c}593300(300 \rightarrow 271 \\
255179151) \\
(271 \rightarrow 243227)\end{array}$ & $\mathrm{C}_{33} \mathrm{H}_{40} \mathrm{O}_{20}$ & $\begin{array}{l}\text { Quercetin-3-O- } \\
\text { di(deoxyhexoside)- } \\
\text { 7-O-hexoside }\end{array}$ & $0.61 \pm 0.01$ \\
\hline 2 & 19.1 & 755 & $\begin{array}{c}593300(300 \rightarrow 271 \\
255179151) \\
(271 \rightarrow 243227)\end{array}$ & $\mathrm{C}_{36} \mathrm{H}_{36} \mathrm{O}_{18}$ & $\begin{array}{c}\text { Quercetin-3- } \\
\text { deoxyhexoside- } \\
\text { hexoside- } \\
\text { deoxyhexoside }\end{array}$ & $0.22 \pm 0.01$ \\
\hline 3 & 18.9 & 609 & $\begin{array}{c}301300(301 \rightarrow 271 \\
255179151) \\
(271 \rightarrow 243227)\end{array}$ & $\mathrm{C}_{27} \mathrm{H}_{30} \mathrm{O}_{16}$ & $\begin{array}{l}\text { Quercetin- } \\
\text { hexoside- } \\
\text { deoxyhexoside }\end{array}$ & $1.59 \pm 0.05$ \\
\hline 4 & 18.5 & 739 & $\begin{array}{c}593577447430285 \\
257\end{array}$ & $\mathrm{C}_{33} \mathrm{H}_{40} \mathrm{O}_{19}$ & $\begin{array}{l}\text { Kaempferol-7-O- } \\
\text { hexoside-3-O- } \\
\text { deoxyhexoside- } \\
\text { deoxyhexoside }\end{array}$ & $3.68 \pm 0.04$ \\
\hline 5 & 19.4 & 755 & $\begin{array}{c}609591489300271 \\
255\end{array}$ & $\mathrm{C}_{36} \mathrm{H}_{36} \mathrm{O}_{18}$ & $\begin{array}{l}\text { Quercetin-3- } \\
\text { deoxyhexoside- } \\
\text { hexoside- } p \text { - } \\
\text { coumaroyl }\end{array}$ & $3.64 \pm 03.04$ \\
\hline 6 & 18.5 & 595 & $\begin{array}{c}463300271255 \\
(300 \rightarrow 271255) \\
(271 \rightarrow 243227215 \\
199)\end{array}$ & $\mathrm{C}_{26} \mathrm{H}_{28} \mathrm{O}_{16}$ & $\begin{array}{l}\text { Quercetin-3- } \\
\text { apiofuranosyl- } \\
\text { glucopyranoside }\end{array}$ & $16.13 \pm 0.04$ \\
\hline 7 & 19.3 & 609 & 301447285255 & $\mathrm{C}_{27} \mathrm{H}_{30} \mathrm{O}_{16}$ & Rutin* & $3.02 \pm 0.04$ \\
\hline 8 & 20.5 & 579 & $\begin{array}{c}447429285 \\
(285 \rightarrow 255) \\
(255 \rightarrow 227213211 \\
187)\end{array}$ & $\mathrm{C}_{25} \mathrm{H}_{28} \mathrm{O}_{15}$ & $\begin{array}{c}\text { Kaempferol-3-O- } \\
\text { hexosyl } \\
\text { pentoside }\end{array}$ & $2.52 \pm 0.06$ \\
\hline 9 & 19.9 & 463 & 301229179 & $\mathrm{C}_{21} \mathrm{H}_{20} \mathrm{O}_{12}$ & $\begin{array}{l}\text { Quercetin-3-O- } \\
\text { glucoside* }^{*}\end{array}$ & $4.21 \pm 0.03$ \\
\hline 10 & 23.1 & 623 & $\begin{array}{c}315300299271255 \\
243(315 \rightarrow 300272 \\
255)\end{array}$ & $\mathrm{C}_{28} \mathrm{H}_{30} \mathrm{O}_{16}$ & $\begin{array}{l}\text { Isorhamnetin-3-O- } \\
\text { rutinoside }^{*}\end{array}$ & $25.91 \pm 0.09$ \\
\hline 11 & 21.6 & 609 & $\begin{array}{c}315301(301 \rightarrow 271 \\
255179151) \\
(271 \rightarrow 243227)\end{array}$ & $\mathrm{C}_{27} \mathrm{H}_{30} \mathrm{O}_{16}$ & $\begin{array}{c}\text { Isorhamnetin } \\
\text {-3-O-hexosyl } \\
\text { pentoside }\end{array}$ & $4.93 \pm 0.03$ \\
\hline
\end{tabular}


Table 2. Cont.

\begin{tabular}{|c|c|c|c|c|c|c|}
\hline $\begin{array}{l}\text { Compound } \\
\text { No. }\end{array}$ & $\begin{array}{l}\text { Retention } \\
\text { Time }\end{array}$ & {$[\mathbf{M}-\mathbf{H}]^{-}$} & Fragments & Formula & $\begin{array}{c}\text { Identification and } \\
\text { Reference }\end{array}$ & $\mathrm{mg} / \mathrm{g}$ \\
\hline \multicolumn{7}{|c|}{ Flavonoid glycosides } \\
\hline 12 & 22.3 & 447 & 301255 & $\mathrm{C}_{21} \mathrm{H}_{20} \mathrm{O}_{11}$ & $\begin{array}{l}\text { Quercetin-3-O- } \\
\text { rhamnoside* }\end{array}$ & $1.39 \pm 0.04$ \\
\hline 13 & 23.5 & 477 & 314285271 & $\mathrm{C}_{21} \mathrm{H}_{20} \mathrm{O}_{11}$ & $\begin{array}{l}\text { Isorhamnetin-7-O- } \\
\text { glucoside }\end{array}$ & $4.46 \pm 0.06$ \\
\hline 14 & 25.8 & 447 & $\begin{array}{c}314285271 \\
(314 \rightarrow 300285271)\end{array}$ & $\mathrm{C}_{21} \mathrm{H}_{20} \mathrm{O}_{11}$ & $\begin{array}{l}\text { Isorhamnetin-7-O- } \\
\text { rhamnoside }\end{array}$ & $1.97 \pm 0.03$ \\
\hline 15 & 21.6 & 593 & 447285 & $\mathrm{C}_{27} \mathrm{H}_{30} \mathrm{O}_{15}$ & $\begin{array}{c}\text { Kaempferol-3-O- } \\
\text { hexosil- } \\
\text { deoxyhexoside }\end{array}$ & $18.00 \pm 0.09$ \\
\hline 16 & 18.4 & 329 & $\begin{array}{c}314299271243226 \\
199\end{array}$ & $\mathrm{C}_{17} \mathrm{H}_{18} \mathrm{O}_{7}$ & Dimethoxy quercetin & $4.49 \pm 0.02$ \\
\hline \multicolumn{7}{|c|}{ Other phenolics } \\
\hline 17 & 2.3 & 341 & 179 & $\mathrm{C}_{15} \mathrm{H}_{18} \mathrm{O}_{9}$ & Caffeic acid hexoside & $4.36 \pm 0.04$ \\
\hline 18 & 5.8 & 315 & 153 & $\mathrm{C}_{13} \mathrm{H}_{16} \mathrm{O}_{9}$ & $\begin{array}{c}\text { Protocatechuic acid } \\
\text { hexoside }\end{array}$ & $5.66 \pm 0.03$ \\
\hline 19 & 7.8 & 401 & 269161 & $\mathrm{C}_{20} \mathrm{H}_{18} \mathrm{O}_{9}$ & $\begin{array}{l}\text { Benzyl alcohol } \\
\text { hexose pentose }\end{array}$ & $4.04 \pm 0.05$ \\
\hline 20 & 11.28 & 487 & 337279261 & $\mathrm{C}_{21} \mathrm{H}_{28} \mathrm{O}_{13}$ & $\begin{array}{c}\text { Synapoyl } \\
\text { pentose-pentose }\end{array}$ & $1.08 \pm 0.02$ \\
\hline 21 & 17.2 & 431 & $\begin{array}{c}261187(187 \rightarrow 125) \\
(125 \rightarrow 97)\end{array}$ & & $\begin{array}{l}\text { Gallic acid benzoic } \\
\text { acid derivative }\end{array}$ & $8.84 \pm 0.03$ \\
\hline 22 & 19.4 & 769 & 605475315299 & $\mathrm{C}_{35} \mathrm{H}_{46} \mathrm{O}_{19}$ & Leonoside A & $10.04 \pm 0.02$ \\
\hline 23 & 20.4 & 755 & 623593315297 & $\mathrm{C}_{34} \mathrm{H}_{44} \mathrm{O}_{19}$ & Forsythoside B & $6.31 \pm 0.05$ \\
\hline 24 & 32.6 & 797 & 603474456327167 & $\mathrm{C}_{37} \mathrm{H}_{50} \mathrm{O}_{19}$ & $\begin{array}{l}\text { Ferruginoside C } \\
\text { isomer }\end{array}$ & $7.60 \pm 0.05$ \\
\hline 25 & 35.5 & 797 & 603474456327167 & $\mathrm{C}_{37} \mathrm{H}_{50} \mathrm{O}_{19}$ & Ferruginoside C & $14.21 \pm 0.08$ \\
\hline 26 & 33.9 & 663 & 517485467 & $\mathrm{C}_{31} \mathrm{H}_{36} \mathrm{O}_{16}$ & $\begin{array}{c}\text { Feruloyl-coumaroyl } \\
\text { saccharose }\end{array}$ & $15.97 \pm 0.08$ \\
\hline 27 & 36.4 & 663 & 517485467 & $\mathrm{C}_{31} \mathrm{H}_{36} \mathrm{O}_{16}$ & $\begin{array}{c}\text { Feruloyl-coumaroyl } \\
\text { saccharose }\end{array}$ & $12.21 \pm 0.08$ \\
\hline 28 & 39.9 & 663 & 517485467 & $\mathrm{C}_{31} \mathrm{H}_{36} \mathrm{O}_{16}$ & $\begin{array}{c}\text { Feruloyl-coumaroyl } \\
\text { saccharose }\end{array}$ & $11.20 \pm 0.06$ \\
\hline 29 & 41.5 & 663 & 517485467 & $\mathrm{C}_{31} \mathrm{H}_{36} \mathrm{O}_{16}$ & $\begin{array}{c}\text { Feruloyl-coumaroyl } \\
\text { saccharose }\end{array}$ & $13.06 \pm 0.09$ \\
\hline 30 & 44.2 & 663 & 517485467 & $\mathrm{C}_{31} \mathrm{H}_{36} \mathrm{O}_{16}$ & $\begin{array}{c}\text { Feruloyl-coumaroyl } \\
\text { saccharose }\end{array}$ & $9.06 \pm 0.07$ \\
\hline \multicolumn{7}{|c|}{ Hydrophylic Terpenoids (positive electrospray (ESI)) } \\
\hline 31 & 13.1 & $\begin{array}{c}433[\mathrm{M}+\mathrm{HCOOH} \\
-\mathrm{H}]^{-}\end{array}$ & $\begin{array}{c}387.5223205161153 \\
\quad(153 \rightarrow 138-122)\end{array}$ & $\begin{array}{c}\mathrm{C}_{19} \mathrm{H}_{32} \mathrm{O}_{8}+ \\
\mathrm{CH}_{2} \mathrm{O}_{2}\end{array}$ & Icariside B5 & $9.15 \pm 0.06$ \\
\hline 32 & 13.9 & $\begin{array}{c}431[\mathrm{M}+\mathrm{HCOOH} \\
-\mathrm{H}]^{-}\end{array}$ & $\begin{array}{c}385.5223205161153 \\
\quad(153 \rightarrow 138-122)\end{array}$ & $\begin{array}{c}\mathrm{C}_{19} \mathrm{H}_{30} \mathrm{O}_{8}+ \\
\mathrm{CH}_{2} \mathrm{O}_{2}\end{array}$ & $\begin{array}{l}\text { Corchoionoside } \\
\text { C/Roseoside }\end{array}$ & $3.63 \pm 0.06$ \\
\hline 33 & 22.97 & 487 & $\begin{array}{c}355337289279261 \\
167\end{array}$ & $\mathrm{C}_{24} \mathrm{H}_{40} \mathrm{O}_{10}$ & $\begin{array}{l}\text { dihydro } \alpha \text { ionol-O- } \\
\text { [arabinosil(1-6) } \\
\text { glucoside] } \\
\text { dihydro } \beta \text { ionol-O- }\end{array}$ & $\begin{array}{c}132.72 \pm \\
0.11\end{array}$ \\
\hline 34 & 24.07 & 487 & 355337289271 & $\mathrm{C}_{24} \mathrm{H}_{40} \mathrm{O}_{10}$ & $\begin{array}{l}\text { [arabinosil(1-6) } \\
\text { glucoside] }\end{array}$ & $79.57 \pm 0.11$ \\
\hline 35 & 53.4 & 331 & 295277215185 & $\mathrm{C}_{20} \mathrm{H}_{28} \mathrm{O}_{4}$ & Kongensin D & $0.72 \pm 0.02$ \\
\hline
\end{tabular}


Table 2. Cont.

\begin{tabular}{|c|c|c|c|c|c|c|}
\hline $\begin{array}{l}\text { Compound } \\
\text { No. }\end{array}$ & $\begin{array}{l}\text { Retention } \\
\text { Time }\end{array}$ & {$[\mathbf{M}-\mathbf{H}]^{-}$} & Fragments & Formula & $\begin{array}{c}\text { Identification and } \\
\text { Reference }\end{array}$ & $\mathrm{mg} / \mathrm{g}$ \\
\hline \multicolumn{7}{|c|}{$\begin{array}{c}\text { Positive } \\
\text { atmospheric } \\
\text { pressure chemical } \\
\text { ionization (APCI) }\end{array}$} \\
\hline \multicolumn{7}{|c|}{$\left[\mathrm{M}-\mathrm{H}_{2} \mathrm{O}+\mathrm{H}\right]^{+}$} \\
\hline 36 & 60.0 & 397 & & $\mathrm{C}_{29} \mathrm{H}_{50} \mathrm{O}$ & $\beta$-sitosterol ${ }^{*}$ & $48.60 \pm 0.14$ \\
\hline 37 & 53.8 & 383 & & $\mathrm{C}_{28} \mathrm{H}_{48} \mathrm{O}$ & Campesterol* & $3.04 \pm 0.08$ \\
\hline 38 & 51.3 & 399 & & $\mathrm{C}_{29} \mathrm{H}_{52} \mathrm{O}$ & Stigmastanol* & $4.37 \pm 0.08$ \\
\hline
\end{tabular}

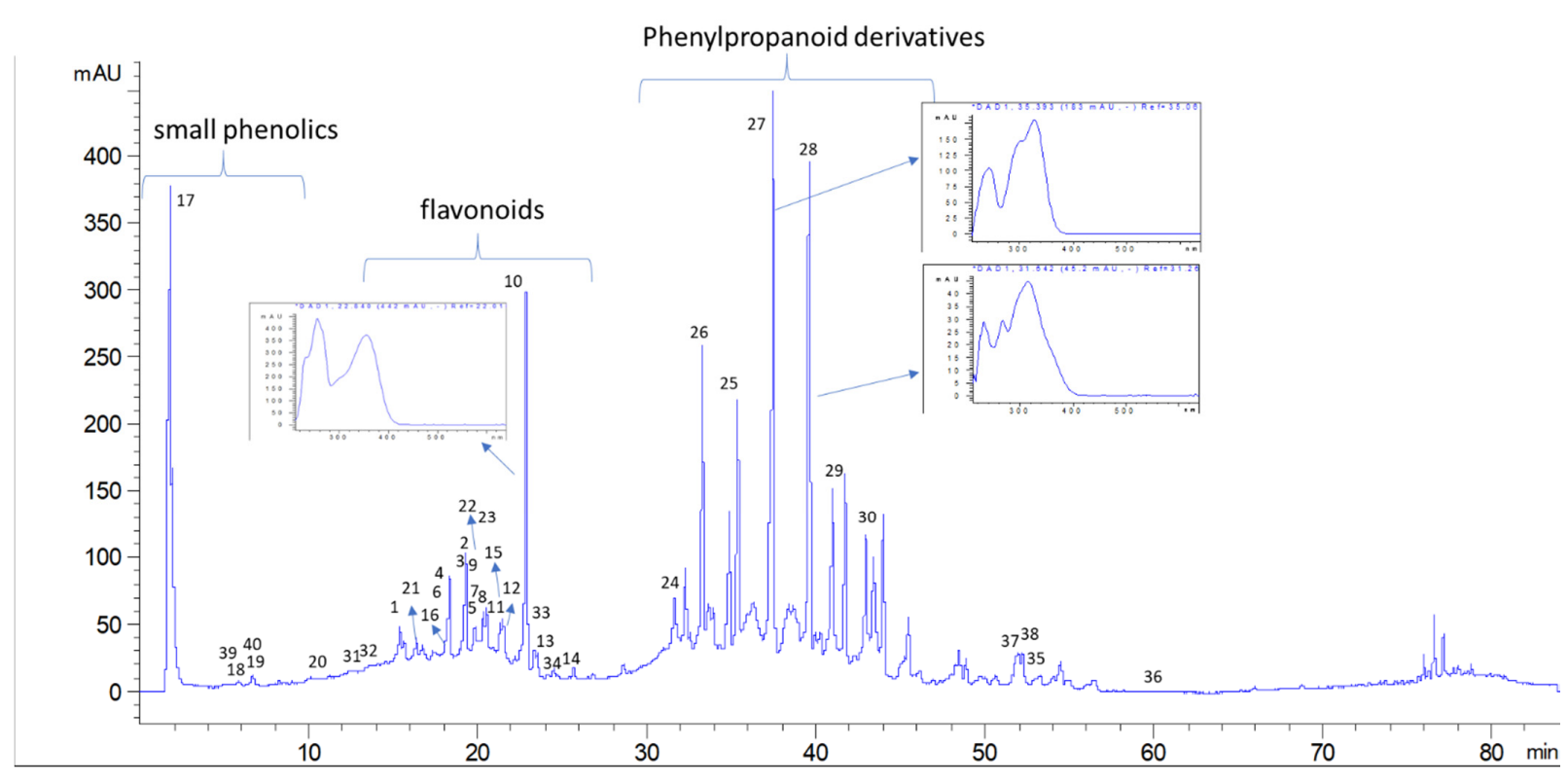

Figure 4. LC-DAD chromatogram $(330 \mathrm{~nm})$ showing the peak group assigned to small phenolics, flavonoids, and phenylpropanoid derivatives; exemplificative UV spectra of the peaks are included. Peaks numbers refer to Table 2.

The LC-DAD chromatogram obtained for the methanol extract showed a series of peaks presenting typical UV spectrums ascribable to flavonoids, hydroxycinnamic acids and small phenolics as represented in Figure 1. Mass spectrometric data were acquired both in negative and in positive ion mode using electrospray source, and the study of MS fragmentation allowed the identification of several derivatives that were quantified based on the diode array chromatographic traces using reference compounds.

Phenolic compounds were abundant in the plant methanol extract. Some small phenolics were detected in the first minutes of the chromatograms. Peaks were assigned to caffeic acid hexoside (17) [9], protocatechuic acid hexoside (18) [9], and benzyl alcohol hexose pentose (19) [10]. The contents of these simple phenolics in the extract was $19 \mathrm{mg} / \mathrm{g}$ of dry extract (Table 2). In the region of 10-13 min in the chromatogram, no significant peaks were detected at wavelength at DAD detector. Nevertheless, two peaks at retention times of 13.1 and 13.8 min were observed in negative mode, suggesting the presence of compounds that lack chromophore (Figure in Supplementary Materials). These peaks present adducts with formic acid $[\mathrm{M}+\mathrm{HCOOH}-\mathrm{H}]^{-}$at $m / z 433$ and 431 and also deprotonated molecular ions $[\mathrm{M}-\mathrm{H}]^{-}$ at $m / z 387$ and 385, respectively. The fragmentation showed the loss of a hexose unit, followed by the loss of the megastigmane moiety $[11,12]$. On the basis of the fragmentation schemes, the peak at $\mathrm{min} 13.1$ was assigned to icariside B5 (31) $(\mathrm{m} / \mathrm{z}$ 387) [13], while the peak at $13.9 \mathrm{~min}$ was assigned to corchoionoside C (32) $(\mathrm{m} / \mathrm{z} 385)$. Spectra and proposed structures of main fragments for the two derivatives are summarized in Figures 5 and 6. 


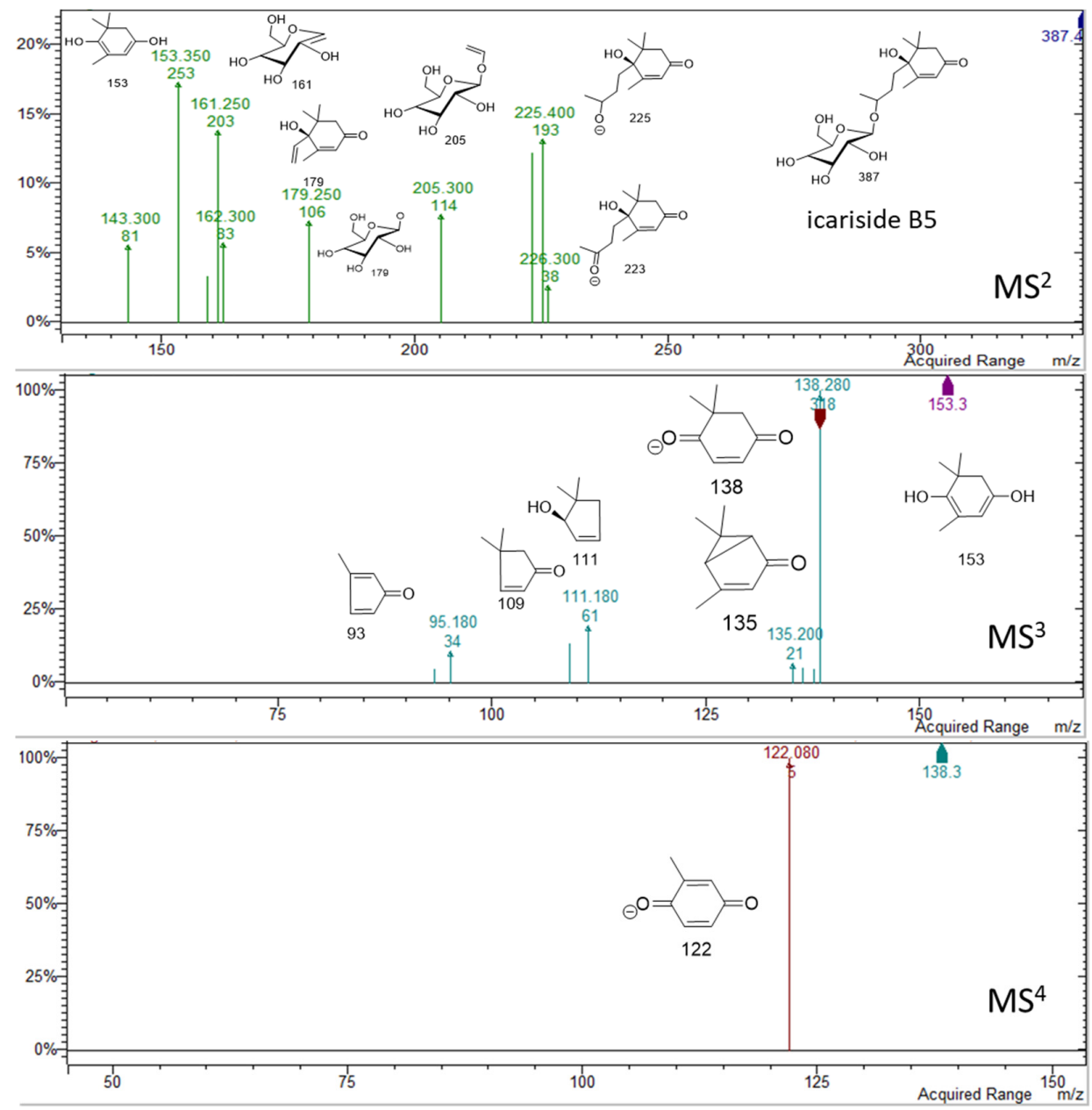

Figure 5. Spectral and fragmentations of icariside B5: $\mathrm{MS}^{2}$ from parent ion $387 \mathrm{~m} / \mathrm{z}, \mathrm{MS}^{3}$ from fragment $153 \mathrm{~m} / \mathrm{z}$, MS 4 from fragment $138 \mathrm{~m} / \mathrm{z}$.

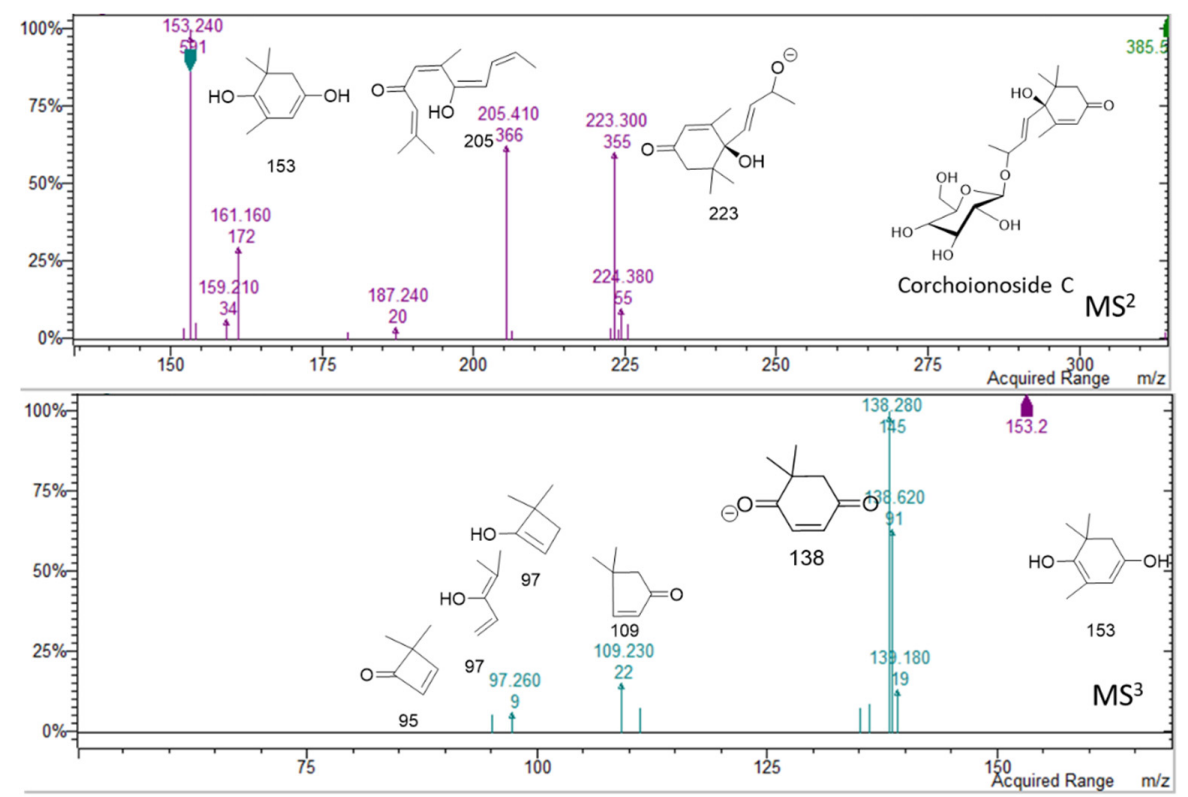

Figure 6. Spectra and fragmentations proposed for corchoionoside C: $\mathrm{MS}^{1}$ from parent ion $385 \mathrm{~m} / \mathrm{z}$, MS ${ }^{2}$ from fragment $153 \mathrm{~m} / \mathrm{z}$. 
In the region of 16-25 min peaks showing UV spectrum typical of flavonols, characterized by maximum absorption in the range of 350 and $265 \mathrm{~nm}$ (Figure 1) [9], were detected. The NMR data showed signals ascribable to flavonoid derivatives as summarized in Table 1 , and the main signals related to aromatic portion are indicated in Figure 4. Kaempferol and quercetin as aglycones can be observed due to the $\mathrm{MS}^{\mathrm{n}}$ fragmentation spectra [14]. Glycosylation position can be tentatively assigned based on the relative intensity of aglycone fragments [14-16]. The amount of flavonoids and their glycosides (1-16) was $96 \mathrm{mg} / \mathrm{g}$ of dried extract. Isorhamnetin-3-O-rutinoside (10), kaempferol-3-O-hexosil-deoxyhexoside (15), and quercetin-3-apiofuranosyl-glucopiranoside (6) were the most abundant derivatives with 25.91, 18.0, and $16.13 \mathrm{mg} / \mathrm{g}$ extract, respectively. LC-MS ${ }^{\mathrm{n}}$ data in negative ion mode, in the region of 23-26 min of the chromatogram, revealed two intense peaks (see Supplementary Material Figure S3) that present $[\mathrm{M}-\mathrm{H}]^{-}$at $m / z 487$. The fragmentation pattern of these two derivatives is reported in Figures 7 and 8 and can be ascribed to two glycosidic derivatives of ionones, based on the comparison with databases, and thus the compounds were identified as dihydro $\alpha$ ionol-O-[arabinosil(1-6) glucoside] and the dihydro $\beta$ ionol-O-[arabinosil(1-6) glucoside]. Their amounts are notable in the extract being 132 and $79 \mathrm{mg}$ /g extract, respectively. Furthermore, different peaks observed in the chromatogram region from 32 to 50 min present UV spectra ascribable to hydroxycinnamic acids. The NMR data confirmed the presence of different units of hydroxycinnamic derivatives due to multiple doublet signals ascribed to the double bond of these compounds. Several peaks can be ascribed to phenylethanoid glycosides (Table 1, Figure 4). At retention time $19.4 \mathrm{~min}$, the $\mathrm{MS}^{\mathrm{n}}$ fragmentation scheme suggests that the structure can be tentatively assigned to leonoside $\mathrm{A}\left(\mathrm{m} / \mathrm{z}\right.$ 769) (22), while at $20.4 \mathrm{~min}$ peak presenting $[\mathrm{M}-\mathrm{H}]^{-}$at $m / z$ 755 can be annotated as forsythoside B (23) [17]. Two derivatives presenting [M $-\mathrm{H}]^{-}$at $\mathrm{m} / \mathrm{z} 797$ are annotated as ferrusinogide $C$ (25) and its isomer (24). Several peaks present adduct with formic acid $[\mathrm{M}+\mathrm{HCOOH}-\mathrm{H}]^{-}$at $m / z 856$ and $[\mathrm{M}-\mathrm{H}]^{-}$at $m / z$ 810. This compound presents fragmentation $\mathrm{MS}^{3}$ with a very strong peak at $m / z 601$ and which further forms fragment ions at $m / z 487,469,451$, and 337. The latter fragment suggests that they are feruloyl quinic acid derivatives. The UV spectrum confirms the presence of a hydroxycinnamic unit, and the fragmentation scheme indicates the presence of triterpene unit or a big portion of sugar, but due to absence of a similar pattern of fragmentation in the literature, we preferred not to assign any structure to those peaks. As these compounds were not identified, they were not included in the table; however, their isolation is in progress.
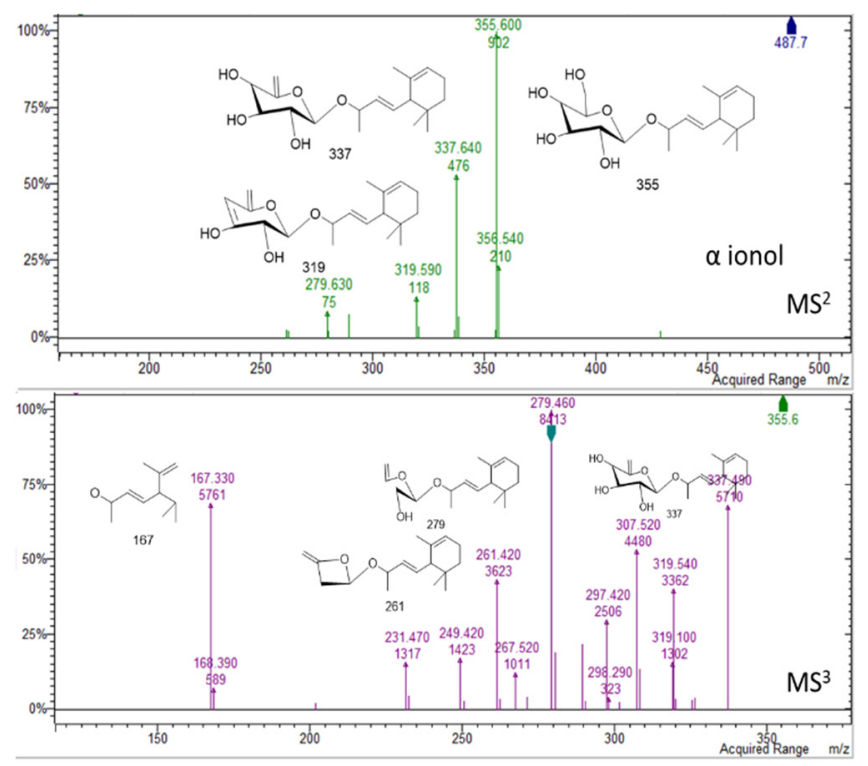

Figure 7. Mass spectral details of dihydro $\alpha$ ionol-O-[arabinosil(1-6) glucoside]. 

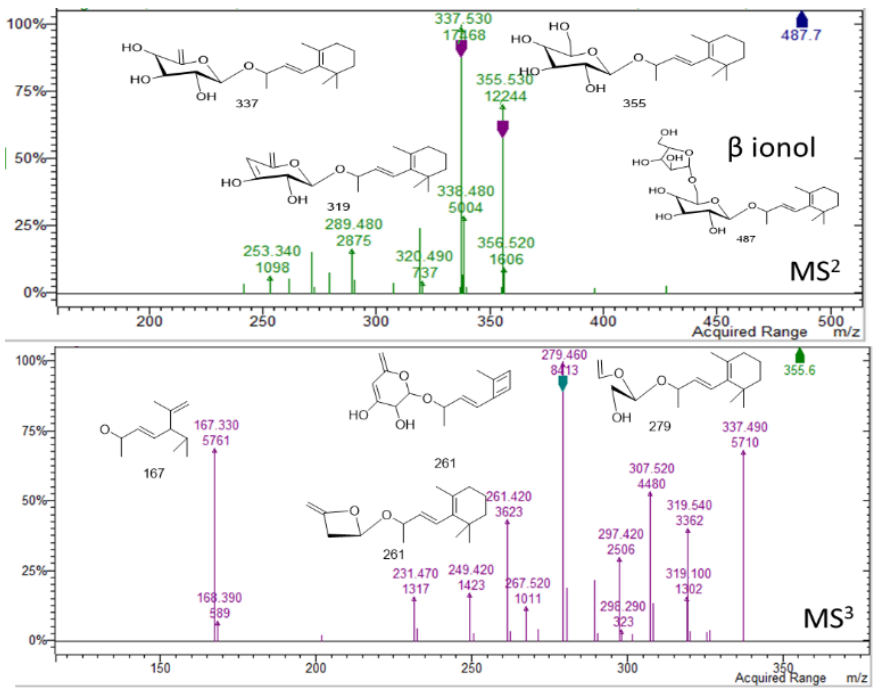

Figure 8. Mass spectral details of dihydro $\beta$ ionol-O-[arabinosil(1-6) glucoside].

Further compounds presenting molecular ion $[\mathrm{M}-\mathrm{H}]^{-}$at $m / z 663$ were assigned to ester of sucrose with ferulic acid and $p$-coumaric acid. Five different isomers (26-30) were observed, probably due to the ester linkages at different positions. From MS spectra, it is not possible to assign the different isomers due to lack of specific literature.

In the extract, the overall amount of phenyl propanoid and phenylethanoid derivatives is $100 \mathrm{mg} / \mathrm{g}$. At $53.4 \mathrm{~min}$, kongensin D (35), a diterpenoid derivative, was identified based on $m / z$ value at 331. Phytosterols were detected using APCI ion source operating in positive ion mode, and $\beta$-sitosterol (36) was the most abundant compound. The results of the fingerprinting showed that the extract contains different classes of compounds, such as phytosterols, flavonoid glycosides, hydroxycinnamic derivatives, megastigmane, and other terpenoids, indicating that $C$. hirtus can be considered as a valuable source of bioactive constituents.

Due to the complex nature of constituents detected in the plant, we decided to perform extraction using water and organic solvents (dichloromethane (DCM)), ethyl acetate (EA), and methanol $(\mathrm{MeOH}))$. Different in vitro assays were then performed using the obtained extracts. The results are illustrated in Table 3. A notable amount of total phenolic content was recorded for all the extracts, ranging from $17.96(\mathrm{MeOH})$ and $24.24(\mathrm{DCM}) \mathrm{mg}$ GAE/g extract. A significant difference in total flavonoid content using different solvents was observed. Among the solvents used, the $\mathrm{MeOH}$ extract $(50.16 \mathrm{mg} \mathrm{RE} / \mathrm{g})$, followed by EA extract (29.28 mg RE/g extract), resulted in the highest total flavonoid content using the spectrophotometric assay. The variation in the yields can be related to the different solvent polarities and to the different solubility and polarity of the phytoconstituents $[18,19]$. Such parameters can also be influenced by the ability of the different solvents to penetrate the plant tissue and to solubilize the classes of compounds.

Table 3. Extraction yields and total bioactive components in the tested extracts *.

\begin{tabular}{cccc}
\hline Extracts & Extraction Yields (\%) & $\begin{array}{c}\text { Total Phenolic } \\
\text { Content (mg GAE/g) }\end{array}$ & $\begin{array}{c}\text { Total Flavonoid } \\
\text { Content (mg RE/g) }\end{array}$ \\
\hline DCM & 2.13 & $24.24 \pm 0.90^{\mathrm{a}}$ & $14.37 \pm 0.12^{\mathrm{c}}$ \\
EA & 2.34 & $22.51 \pm 0.52^{\mathrm{b}}$ & $29.28 \pm 1.89^{\mathrm{b}}$ \\
Infusion & 9.95 & $22.38 \pm 0.34^{\mathrm{b}}$ & $12.54 \pm 0.32^{\mathrm{c}}$ \\
MeOH & 13.18 & $17.96 \pm 0.03^{\mathrm{c}}$ & $50.16 \pm 2.53^{\mathrm{a}}$ \\
\hline
\end{tabular}

*Values expressed are means \pm S.D. of three parallel measurements. GAE: Gallic acid equivalent; RE: Rutin equivalent. Different letters indicate significant differences in the extracts $(p<0.05)$. 


\subsection{Antioxidant Ability}

Oxidative stress is a phenomenon that arises when reactive oxygen species overwhelms the intrinsic antioxidant defense mechanism. Considerable evidence implicates oxidative stress in the pathophysiology of many diseases and associated complications including diabetes, cardiovascular diseases, and dementia [20,21]. As synthetic antioxidants such as butylated hydroxytoluene (BHT) and butylated hydroxyanisole (BHA) have been reported to exert negative effects on human health, there is a renewed interest to find novel antioxidant compounds with more efficacy and minimal or no side effects. In this context, medicinal plants in particular have been widely studied for discovering potential novel antioxidant molecules [22]. Some of Croton species that have been reported for their antioxidant capacity include C. celtidifolius Baill. [23], C. lechleri Muell.-Arg. [24], C. zambesicus Muell.-Arg. [25], and C. cajucara Benth. [26].

Therefore, this investigation also endeavored to evaluate the antioxidant potential of the different extracts of $C$. hirtus by employing different in vitro bioassays-namely, free radical scavenging (DPPH and ABTS), reducing power (CUPRAC and FRAP), phosphomolybdenum, and ferrous-ion chelating assays. As illustrated in Table 4, different extracts possessed varied free radical scavenging and reducing capacities. The results of DPPH and ABTS assays indicated that the water extract displayed the highest free radical scavenging ability, with a mean value of 41.08 and $64.84 \mathrm{mg}$ TE/g extract, respectively. For CUPRAC assay, the DCM (88.67 mg TE/g extract) extract, followed by water (78.17 mg TE/g extract) extract, showed highest reducing power. The order of the FRAP assay was water $>\mathrm{MeOH}$ $>$ DCM > EA. This indicates that the hydrophilic compounds in the extract are, in general, mostly involved in the antioxidant effect in the assays' conditions. Considering the fingerprinting chemical analysis, these effects can be probably ascribed to hydroxycinnamic and flavonoid derivatives. This observation is in agreement with a previous report that demonstrated that highly polar solvents, such as water and methanol, have a high effectiveness as antioxidants [22]. In the literature, we observed different results for different solvent extracts $[27,28]$. For example, although polar extracts had the highest levels of phenolic compounds in some studies, apolar extracts exhibited stronger free radical and reducing abilities. This fact can be explained by different reasons. For example, the spectrophotometric assays could have some drawbacks, and not only phenolics but also other classes of compounds could play a role. Furthermore, reaction conditions, organic solvent, aqueous buffer, and $\mathrm{pH}$ influence the experimental response of the mixture and compounds, leading to different effects in the antioxidant reactions. Altogether, the utilization of more assays could provide accurate information of the antioxidant capacity of plant extracts.

Table 4. Antioxidant properties of the tested extracts *

\begin{tabular}{ccccccc}
\hline Extracts & $\begin{array}{c}\text { DPPH } \\
(\mathbf{m g T E} / \mathbf{g})\end{array}$ & $\begin{array}{c}\text { ABTS } \\
(\mathbf{m g T E} / \mathbf{g})\end{array}$ & $\begin{array}{c}\text { CUPRAC } \\
\text { (mgTE/g) }\end{array}$ & $\begin{array}{c}\text { FRAP } \\
\text { (mgTE/g) }\end{array}$ & $\begin{array}{c}\text { Phosphomolybdenum } \\
\text { (mmol TE/g) }\end{array}$ & $\begin{array}{c}\text { Chelating } \\
\text { Ability (mg } \\
\text { EDTAE/g) }\end{array}$ \\
\hline DCM & $22.78 \pm 0.52^{\mathrm{c}}$ & $32.32 \pm 2.49^{\mathrm{c}}$ & $88.67 \pm 1.08^{\mathrm{a}}$ & $26.35 \pm 0.09^{\mathrm{c}}$ & $2.70 \pm 0.13^{\mathrm{a}}$ & $15.18 \pm 1.08^{\mathrm{b}}$ \\
$\mathrm{EA}$ & $23.66 \pm 1.14^{\mathrm{c}}$ & $18.59 \pm 1.64^{\mathrm{d}}$ & $69.04 \pm 0.40^{\mathrm{c}}$ & $24.15 \pm 0.21^{\mathrm{d}}$ & $2.33 \pm 0.27^{\mathrm{ab}}$ & $18.26 \pm 0.22^{\mathrm{a}}$ \\
Infusion & $41.08 \pm 1.65^{\mathrm{a}}$ & $64.84 \pm 2.71^{\mathrm{a}}$ & $78.17 \pm 0.16^{\mathrm{b}}$ & $45.67 \pm 0.86^{\mathrm{a}}$ & $1.46^{\mathrm{b}} \pm 0.01^{\mathrm{c}}$ & $17.94 \pm 0.16^{\mathrm{a}}$ \\
$\mathrm{MeOH}$ & $30.62 \pm 0.54^{\mathrm{b}}$ & $42.02 \pm 1.11^{\mathrm{b}}$ & $62.50 \pm 2.30^{\mathrm{d}}$ & $30.94 \pm 0.35^{\mathrm{b}}$ & $1.97 \pm 0.10^{\mathrm{b}}$ & $13.96 \pm 0.10^{\mathrm{b}}$ \\
\hline
\end{tabular}

${ }^{*}$ Values expressed are means \pm S.D. of three parallel measurements. TE: Trolox equivalent; EDTAE: EDTA equivalent. Different letters indicate significant differences in the extracts $(p<0.05)$.

The phosphomolybdenum assay was employed to estimate the total antioxidant capacity of the $C$. hirtus extracts. The DCM extract was found to show the highest total antioxidant capacity, with a mean value of $2.70 \mathrm{mmol} \mathrm{TE} / \mathrm{g}$ extract. In the case of ferrousion chelating activity, the EA (18.26 mg EDTAE/g extract) and water (17.94 mg EDTAE/g extract) extracts showed the highest activity. In total, despite of its lower total phenolic and flavonoid contents, the water extract showed considerably higher antioxidant capacity as compared with other tested extracts. Such results suggest lipophilic fraction has a role in 
mediating the antioxidant effects, and some effect can also be ascribed to fatty acid and phytosterols that have been reported as significant antioxidant compounds [29-31].

In the literature, the extracts of some Croton species and their isolated compounds exhibited remarkable antioxidant properties. For example, Aderogba et al. [25] isolated three compounds from C. zambesicus and one of them displayed good DPPH radical scavenging ability with an $\mathrm{IC}_{50}$ value of $200 \mu \mathrm{M}$. Similarly, Azevedo et al. [26] reported significant radical scavenging abilities of $C$. cajucara isolated compounds. When combining all data on the genus Croton, they could be considered as a significant source of natural antioxidants.

\subsection{Enzyme Inhibitory Ability}

Due to their essential catalytic role in several physiological processes, enzymes are considered as prime targets for drug design for alleviating diseases. Indeed, the therapy of some important human aliments—namely, hypertension, diabetes, inflammatory and neurodegenerative diseases-includes the use of enzyme inhibitors. For instance, $\alpha$-amylase and $\alpha$-glucosidase enzymes are the targeted enzymes in diabetes, while cholinesterases (acetylcholinesterase and butyrylcholinesterase) are the known therapeutic targets in Alzheimer's disease [32,33].

The inhibitory action of the studied C. hirtus extracts against cholinesterase, tyrosinase, $\alpha$-amylase, and $\alpha$-glucosidase were determined. Table 5 illustrates the inhibitory potential of the different extracts against the studied enzymes, expressed as equivalent values of standards. The tested solvents displayed significantly distinct inhibitory potentials against AChE, with the DCM and EA extracts (5.03 mg GALAE/g extract, $4.84 \mathrm{mg}$ GALAE/g extract) being most potent but with significant effect for methanol (4.05 mg GALAE/g extract). All the extracts showed remarkable anti-BChE effects, with mean values ranging from 16.41 to $15.86 \mathrm{mg}$ GALAE/g extract. This result suggests that different constituents of the plant may exert inhibitory activity on these enzymes. With respect to the composition of the methanol extract, quercetin, kaempferol, and isorhamnetin derivatives detected in the extract have been previously documented as AChE inhibitors [34-36]. In particular, quercetin-3-apiofuranosyl-glucopyranoside, isorhamnetin-3-O-rutinoside, and kaempferol3-O-hexosil-deoxyhexoside, which are detected in high level in the methanol extracts, could be potentially the main flavonoid derivatives, attributing to the anti-AChE effects. Rutin was also reported by Szwajgier et al. [37] as a significant cholinesterase agent. Furthermore, as previously reported, the hydroxycinnamic acids, such as caffeic acid hexoside and protocatechuic acid hexoside, detected in the extract could be potent AChE inhibitors [34]. For the lipophilic extracts, it can be postulated that the effects were mediated by the presence of phytosterols, particularly $\beta$-sitosterol, which have been reported as AChE and BChE inhibitors [38].

Table 5. Enzyme inhibitory properties of the tested extracts *.

\begin{tabular}{cccccc}
\hline Extracts & $\begin{array}{c}\text { AChE Inhibition } \\
\text { (mgGALAE/g) }\end{array}$ & $\begin{array}{c}\text { BChE Inhibition } \\
\text { (mgGALAE/g) }\end{array}$ & $\begin{array}{c}\text { Tyrosinase } \\
\text { Inhibition } \\
\text { (mgKAE/g) }\end{array}$ & $\begin{array}{c}\text { Amylase } \\
\text { Inhibition } \\
\text { (mmolACAE/g) }\end{array}$ & $\begin{array}{c}\text { Glucosidase } \\
\text { Inhibition (mmol } \\
\text { ACAE/g) }\end{array}$ \\
\hline DCM & $5.03 \pm 0.16^{\mathrm{a}}$ & $16.41 \pm 1.68^{\mathrm{a}}$ & $24.39 \pm 0.98^{\mathrm{c}}$ & $0.71 \pm 0.01^{\mathrm{ab}}$ & $1.68 \pm 0.14$ \\
EA & $4.84 \pm 0.19^{\mathrm{a}}$ & $15.86 \pm 0.74^{\mathrm{a}}$ & $34.81 \pm 2.67^{\mathrm{b}}$ & $0.75 \pm 0.03^{\mathrm{a}}$ & $\mathrm{na}$ \\
Infusion & $1.01 \pm 0.13^{\mathrm{c}}$ & $14.44 \pm 0.34^{\mathrm{a}}$ & $\mathrm{na}$ & $0.14 \pm 0.01^{\mathrm{c}}$ & $\mathrm{na}$ \\
MeOH & $4.09 \pm 0.02^{\mathrm{b}}$ & $16.11 \pm 0.25^{\mathrm{a}}$ & $49.83 \pm 3.94^{\mathrm{a}}$ & $0.69 \pm 0.02^{\mathrm{b}}$ & $\mathrm{na}$ \\
\hline
\end{tabular}

* Values expressed are means \pm S.D. of three parallel measurements. GALAE: Galatamine equivalent; KAE: Kojic acid equivalent; ACAE: Acarbose equivalent. na: not active. Different letters indicate significant differences in the extracts $(p<0.05)$.

All the extracts except the water extract showed considerable tyrosinase inhibition, with values of 49.83, 34.81, and $24.39 \mathrm{mg} \mathrm{KAE/g} \mathrm{extract} \mathrm{for} \mathrm{MeOH,} \mathrm{EA,} \mathrm{and} \mathrm{DCM,} \mathrm{re-}$ spectively. Most of the activity can be correlated to hydrophilic phenolic compounds, but as we described for $\mathrm{AChE}$ and $\mathrm{BChE}$, a significant role is clearly indicated also by results for the lipophilic constituents. Modest activity against $\alpha$-amylase activity was exerted by all the extracts $(0.14-0.75 \mathrm{nmol} \mathrm{ACAE} / \mathrm{g}$ extract), whilst only the DCM extract 
(1.68 nmol ACAE/g) was effective at inhibiting $\alpha$-glucosidase. Similar to cholinesterases' inhibitory ability, the other enzyme inhibitory abilities could be attributed to the presence of chemical components identified, including rutin, caffeic acid, and protocatechuic acid [39-42]. Literature search on the enzyme inhibitory properties of the genus Croton resulted in a few studies on the subject. Aderogba et al. [25] reported on the inhibitory properties of flavonols and indol alkaloids from C. menyharthii against acetylcholinesterase, and glucosidase and especially alkaloids exhibited significant acetylcholinesterase abilities. Similarly, Shahwar et al. [43] isolated some alkaloids from C. sparsiflorus, and most of them had excellent acetylcholinesterase inhibitory properties. Keerthana et al. [44] reported significant amylase inhibition capacity for $C$. bonplandianum ethanolic leaf extract. The remarkable glucosidase inhibitory properties of $C$. thurifer components were also described by Morocho et al. [45]. With all observations, the genus Croton could be considered as a source of great potential for natural enzyme inhibitors to combat global health problems.

\subsection{K-Medoids Clustering}

Following the initial screening of biological activities of the prepared extracts by univariate analysis, $k$-medoids cluster analysis was performed with aim of assessing the effects of the solvents used for extraction. The $k$-medoids model is a robust clustering approach for identifying and partitioning a dataset into an optimal number of homogeneous clusters. This approach allowed us to visually evaluate the clustering tendency of the samples from the very beginning. As observed in Figure 9, there is a low similarity among the subjects representing each solvent (Figure 9A). This points out a high intra-class similarity and low inter-class similarity and confirms that there is a cluster structure in the $C$. hirtus biological activities dataset. Based on Figure 9B, it can be observed the optimal number of clusters is 4 . Figure $9 \mathrm{C}$ depicts the $k$-medoids scatter plot, and it can be observed that the samples were grouped depending on the solvents used and distributed differently in the hyperspace along the two dimensions. Therefore, this statistical approach demonstrated that the biological activities of $C$. hirtus were influenced by the extraction solvents. Notably, the cluster validation was found to be excellent, being 0.69 for the silhouette coefficient, thus confirming the goodness of the $k$-medoids model (Figure 9D).

Many researchers have studied and evaluated the effect of different types of solvents on biological activities of various Croton species [1,23-25]. These studies indicated that the selectivity of the solvent is crucial not only for obtaining optimum yield of one or more desired molecules but also for pharmacological effects of the resulting molecules. In fact, secondary metabolites possess different degrees of polarity; thereby, the extractive solvent should be chosen carefully to ensure a good dissolution of secondary metabolites intended to be studied. For example, aqueous solvent with a dielectric constant of 80 dissolves polar molecules more rapidly than non-polar solvent hexane due to its low dielectric constant of 1.89 . 

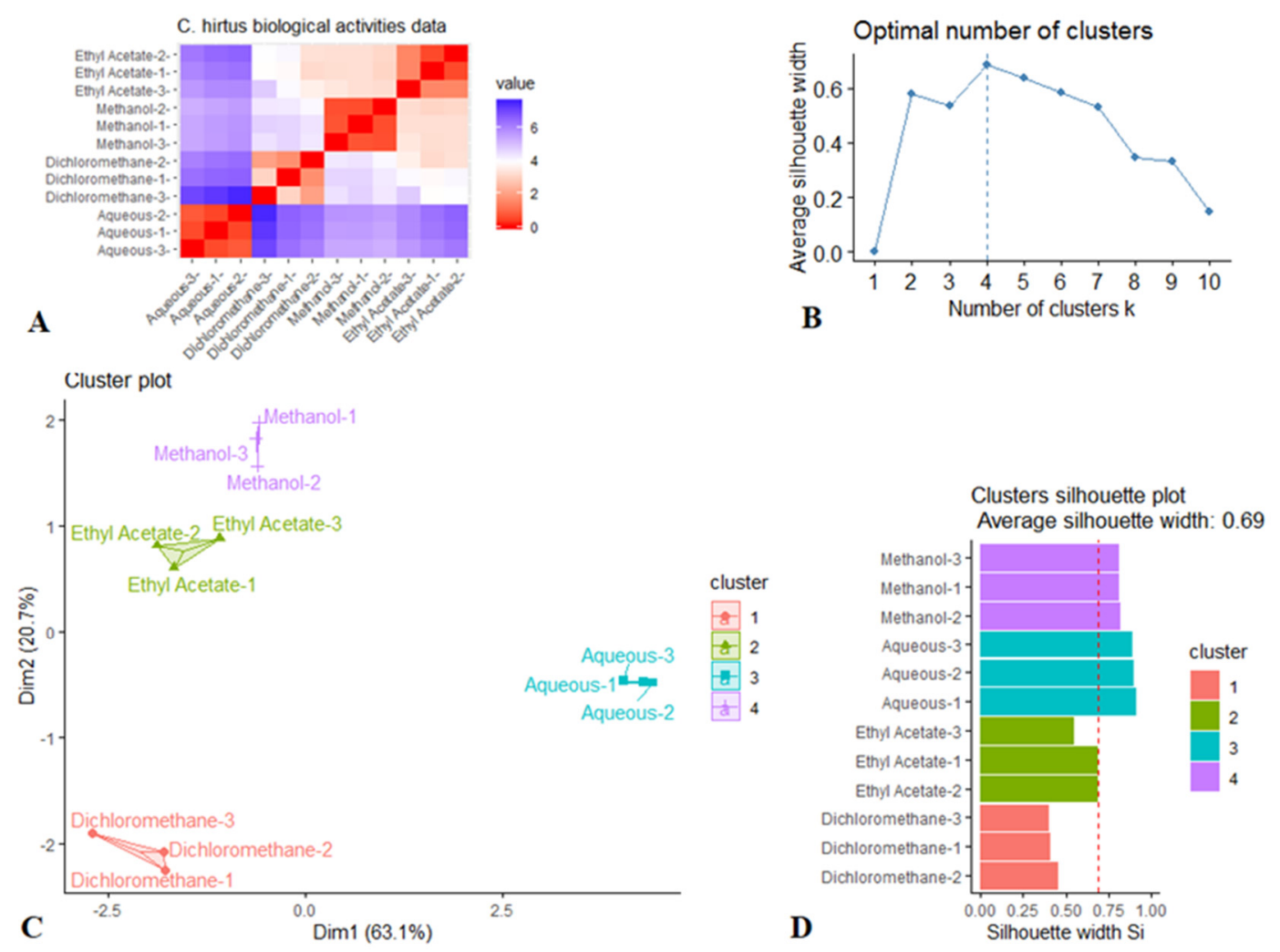

Figure 9. A $k$-medoids clustering analysis of biological activities of $C$. hirtus. (A) Distance matrix showing the dissimilarity between each pair of subjects (Red color: high similarity, Blue color: low similarity). (B) Number of clusters. (C) Scatter plot. (D) Silhouette plot displaying the average distance between clusters.

\section{Materials and Methods}

\subsection{Preparation of Extracts}

Plant samples were collected from Lolobo (Yamoussoukro) of Ivory Coast in 2019 (during summer season) and identified by Ouattara Katinan Etienne (Botanist at Université Félix Houphouet Boigny, Ivory Coast). The plant samples were deposited in the Department of Biology at Selcuk University. The roots were removed and the aerial parts (whole plant with flowers, stems, and foliar tissue) were used. The plant materials were dried in shade for about 10 days and then grounded using a laboratory mill.

In this study, different extraction procedures were employed. As starting point, methanol was used as solvent. At a later stage, solvents with different polarities (dichloromethane, ethyl acetate, water) were also used. Maceration technique was used for dichloromethane, ethyl acetate, and methanol. For this purpose, $5 \mathrm{~g}$ of the samples were macerated with respective solvents (individually) for $24 \mathrm{~h}$ at room temperature $\left(24^{\circ} \mathrm{C} \pm 1\right)$ on a magnetic stirrer, and solvents were changed twice. The mixtures then were filtered and concentrated using a rotary-evaporator. With respect to the water extract, $5 \mathrm{~g}$ of the plant material was infused in $100 \mathrm{~mL}$ boiled water. Then, the water was dried by using freeze-drying. All the extracts were stored $+4{ }^{\circ} \mathrm{C}$ until further studies.

\subsection{Spectrophotometric Assays for Total Phenolic and Flavonoids}

Total phenolic and flavonoid contents of $C$. hirtus extracts were assayed by colorimetric methods according to Zengin and Aktumsek [46]. Gallic acid (GAE) and rutin (RE) were chosen as standards for phenols and flavonoids, respectively.

\subsection{Fingerprinting of Phytoconstituents by LC-DAD-ESI-MS ${ }^{n}, L C-D A D-A P C I-M S^{n}$}

Dried methanol extract $(100 \mathrm{mg}$ ) was dissolved in $15 \mathrm{~mL}$ of methanol and then subjected to sonication for $15 \mathrm{~min}$ at room temperature. The sample was centrifuged at 
$13,000 \mathrm{rpm}$, and the supernatant was removed and used for analysis. For the mass spectrometry detection, we used electrospray (ESI) source for phenolics, atmospheric pressure chemical ionization (APCI) ion source for lipophilic compounds as phytosterols and triterpene. Apparatus used was Agilent 1260 chromatograph (Santa Clara, CA, USA) equipped with 1260 diode array detector (DAD) and Varian MS-500 ion trap mass spectrometer equipped with ESI or APCI ion source (Varian inc, Palo Alto, CA, USA). A "T" splitter was installed immediately after chromatographic column allowing the separation of the eluate, half to DAD and half to Agilent/Varian MS-500 ion trap mass spectrometer. UV-Vis spectra were acquired in the range of $190-400 \mathrm{~nm}$.

For the phenolic analysis, synergy RP polar (Phenomenex, Bologna, Italy) was used as stationary phase $\left(3.0 \times 150 \mathrm{~m}^{2} ; 4\right.$ micron $)$ and as eluents, water $1 \%$ formic acid (A) and methanol (B) were used. Elution gradient started with $95 \%$ of A and went to $10 \%$ of $A$ in $50 \mathrm{~min}$, then the amount of B was increased to $100 \%$ in $55 \mathrm{~min}$. The flow rate was $400 \mu \mathrm{L} / \mathrm{min}$. The MS spectra were acquired in negative ion mode in $50-2000 \mathrm{~m} / \mathrm{z}$ range using an ESI source; drying gas temperature started at $295^{\circ} \mathrm{C}$ and in $40 \mathrm{~min}$ decreased to 250; drying gas pressure was $25 \mathrm{psi}$; nebulizer was $30 \mathrm{psi}$; needle was set at $4500 \mathrm{~V}, \mathrm{RF} 85 \%$, capillary $80 \mathrm{~V}$. Quantification of compounds was obtained using DAD. Chlorogenic acid solutions (of concentration ranging from 100 to $1 \mu \mathrm{g} / \mathrm{mL}$ ) were used to create calibration curve for the quantification of the different hydroxycinnamic acid derivatives at $330 \mathrm{~nm}$. Calibration curve was $Y=43.325 x+0.236\left(R^{2}=0.9989\right)$. For the quantification of flavonols, quercetin and kaempferol solutions (range 100-1 $\mu \mathrm{g} / \mathrm{mL}$ ) were used at $350 \mathrm{~nm}$, and calibration curves were $\mathrm{Y}=25.3 \mathrm{x}+0.55\left(R^{2}=0.9998\right)$ and $\mathrm{Y}=20.3 \mathrm{x}+0.91\left(R^{2}=0.9991\right)$, respectively. Rutin was used for quantification of quercetin glycosides; isorhamnetin-7$\mathrm{O}$-glucoside and kaempferol-3-O-glucoside were used for quantification of isorhamnetin and kaempferol derivatives. Solutions were prepared in the range of $120-0.61 \mu \mathrm{g} / \mathrm{mL}$, and chromatograms were recorded at $350 \mathrm{~nm}$; calibration curves were $Y=31.62 \mathrm{x}+1.021$ $\left(R^{2}=0.9993\right), Y=33.11 x+0.841\left(R^{2}=0.9991\right)$, and $\mathrm{Y}=23.42 \mathrm{x}+1.042\left(R^{2}=0.9989\right)$ for rutin, isorhamnetin-7-O-glucoside, and kaempferol-3-O-glucoside, respectively. Benzoic acid was used for protocatechuic acid and small phenolics using solutions (of concentration ranging from $130-1.30 \mu \mathrm{g} / \mathrm{mL})$ at $280 \mathrm{~nm}$ and calibration curve was $Y=81.1 \mathrm{x}+0.98\left(R^{2}=0.9996\right)$. For terpenoids, a mixture of dihydro $\alpha$ ionol-O-[arabinosil(1-6) glucoside] and dihydro $\beta$ ionol-O-[arabinosil(1-6) glucoside was purified using an Agilent 1260 chromatograph equipped with analytical fraction collector. As stationary phase, an Agilent XDB C18 $3.0 \times 150 \mathrm{~m}^{2}$ was used, and isocratic elution was used (70\% water $0.1 \%$ formic acid, 30\% methanol) at flow rate of $4 \mathrm{~mL} / \mathrm{min}$. Fraction containing compounds were pooled and dried under nitrogen flow and redissolved in deuterated methanol. The amount of $\alpha$ ionol-O-[arabinosil(1-6) glucoside] and dihydro $\beta$ ionol-O-[arabinosil(1-6) glucoside] in the mixture was determined using quantitative NMR with a previously published procedure that used caffeine as internal standard [47]. Solvent was then removed and a solution in methanol was prepared and diluted preparing solutions in the range of 300-1.0 $\mu \mathrm{g} / \mathrm{mL}$. Calibration curve was $\mathrm{Y}=115.1 \mathrm{x}+10.321\left(R^{2}=0.9989\right)$ using MS detector in negative ion mode.

\subsection{HPLC-(APCI)-MS Analysis of Phytosterols}

For the phytosterol constituents, an Agilent Zorbax Eclipse XDB-C18 column (Agilent, Santa Clara, CA, USA) $(3.0 \mathrm{~mm} \times 150 \mathrm{~mm}, 3.5 \mu \mathrm{m})$ was used as stationary phase. All analytical details are described in our previous publications [48]. The compounds were identified based on the comparison with the literature and reference compounds, when available. As standards, known solutions of $\beta$-sitosterol (of concentration ranging from 176 to $1.76 \mu \mathrm{g} / \mathrm{mL}$ ) and stigmasterol (of concentration ranging from 185.6 to $1.9 \mu \mathrm{g} / \mathrm{mL}$ ) were used.

Compound's quantification was obtained via calibration curve derived from $\beta$-sitosterol and stigmasterol solutions. Calibration curves were $Y=0.63 x+0.2705\left(R^{2}=0.99611\right)$ for $\beta$-sitosterol and $Y=2.1153 x-15.216\left(R^{2}=0.9949\right)$ for stigmasterol. 


\subsection{NMR Analysis}

1D and 2D NMR spectra were obtained on a Bruker Avance III 400 Ultrashield spectrometer with $400 \mathrm{MHz}$ magnet. NMR spectra were acquired in MeOD-d4 (Sigma-Aldrich) with TMS as an internal standard. Duran ${ }^{\circledR} 4.95 \mathrm{~mm}$ NMR tubes (Duran Group, Mainz, Germany) were used. Chemical shifts are expressed in $\delta$ values in ppm. ${ }^{1} \mathrm{H}-\mathrm{NMR}$ and HSQC-DEPT, HMBC, and COSY experiments were acquired using standard Bruker sequences measuring $\mathrm{p} 1$ and $\mathrm{d} 1$ for each acquired sample. Samples of dried extract were initially dissolved in $100 \mathrm{mg}$ in MeOD- $d_{4}$ then centrifuged, and the liquid was used for NMR measurements. DOSY experiments were performed using the ledbpgp2s sequence.

\subsection{Determination of Antioxidant and Enzyme Inhibitory Effects}

To detect antioxidant properties, we used several chemical assays including different mechanisms-namely, radical scavenging, reducing power and metal chelating. Trolox (TE) and ethylenediaminetetraacetic acid (EDTA) were used as standard antioxidant compounds. The results are expressed as equivalents of the aforementioned compounds. To detect inhibitory effects on enzymes, we used colorimetric enzyme inhibition assays, and these assays included tyrosinase, $\alpha$-glucosidase, $\alpha$-amylase, and cholinesterases. Standard inhibitors (galantamine for cholinesterases, kojic acid for tyrosinase, and acarbose for $\alpha$-glucosidase and $\alpha$-amylase) were used as positive controls [49]. The experimental details are given in Supplementary Materials.

\subsection{Statistical Analysis}

A one-way analysis of the variance (ANOVA) was performed to investigate significant differences $(p<0.05$, Turkey's post hoc test) for each assay done. Thereafter, the dataset was submitted to $k$-medoids cluster analysis after the distance matrix was visualized for measuring the (dis)similarity between the observations. Euclidean distance measure was used for this purpose. To estimate the optimal number of clusters, the average silhouette method was used. A high average silhouette width indicated a good clustering solution. Finally, the goodness of the $k$-medoids clustering was evaluated by estimating the silhouette coefficient $\left(S_{i}\right)$. A value of $S_{i}$ close to 1 confirmed a good clustering solution. The statistical analysis was performed by using R 3.5.1 software (R Core Team, Vienna, Austria).

\section{Conclusions}

The present study offers a new perspective in the potential use of $C$. hirtus as a source of bioactive constituents. Fingerprinting showed the different plant constituents and suggested the possibility of extracting significant amounts of different classes of compounds-terpenoids, phytosterols, phenolics-from plant material using methanol as solvent. Notable antioxidant and enzyme inhibitory effects against cholinesterases (AChE and $\mathrm{BChE}$ ) and tyrosinase were displayed by the extracts. Among the tested solvents, the polar solvents (water and $\mathrm{MeOH}$ ) were the best solvents for extracting bioactive compounds with antioxidant properties from $C$. hirtus, whilst the $\mathrm{MeOH}, \mathrm{DCM}$, and EA were suitable for obtaining biomolecules with enzyme inhibitory potentials, suggesting that multiple constituents in the extracts being soluble in different solvents exerted inhibitory activity on the same enzyme. This suggests a rationale for the use of the overall mixture, which can offer the opportunity to act on the same target compounds with different physicochemical properties. Based on the present findings, C. hirtus can be considered as a valuable source of pharmacologically active agents and used for designing phytomedicines. Nonetheless, further investigations are essential to elucidate the mode of action of the antioxidant and the enzyme inhibition activity, toxicity, safety, and bioavailability of the extracts.

Supplementary Materials: Supplementary materials are available online, S1: Croton methanol extract H-NMR spectrum; Croton methanol extract HSQC-NMR spectrum enlargement of aromatic portion; Croton methanol extract HMBC spectrum; Croton methanol extract DOSY spectrum; S2: LCMS in negative ion mode showing the two peaks and relative mass spectra ascribable to Icariside 
B5 ([M + HCOOH - H]- ion at $m / z$ 433) and Corchionoside([M + $\mathrm{HCOOH}-\mathrm{H}]-$ ion at $m / z$ 431); S3: LC-MS in negative ion mode showing the two peaks and relative mass spectra ascribable to dihydro $\alpha$ ionol-O-[arabinosil(1-6) glucoside] and the dihydro $\beta$ ionol- $O$-[arabinosil(1-6) glucoside]. Ions are detected as $[\mathrm{M}+\mathrm{HCOOH}-\mathrm{H}]$-and also as $[\mathrm{M}-\mathrm{H}]$ - as visible in figure.

Author Contributions: Conceptualization, S.D., K.I.S., S.S., and G.Z.; methodology, S.D., S.S., I.F., and G.Z.; software, K.I.S. and I.F.; validation, S.D., M.F.M., and G.Z.; formal analysis, G.Z.; investigation, K.I.S. and D.L.; resources, K.I.S. and O.K.E.; data curation, S.D., M.F.M., and G.Z.; writing—original draft preparation, S.D., M.F.M., and D.L.; writing—review and editing, G.Z.; visualization, K.I.S., I.F., and S.S.; supervision, S.S.; project administration, G.Z.; funding acquisition, S.S. All authors have read and agreed to the published version of the manuscript.

Funding: This research received no external funding.

Institutional Review Board Statement: Not applicable.

Informed Consent Statement: Not applicable.

Data Availability Statement: Data is not available from the authors.

Conflicts of Interest: The authors declare no conflict of interest.

Sample Availability: Samples of the compounds are not available from the authors.

\section{References}

1. Salatino, A.; Salatino, M.L.F.; Negri, G. Traditional uses, chemistry and pharmacology of Croton species (Euphorbiaceae). J. Braz. Chem. Soc. 2007, 18, 11-33. [CrossRef]

2. Daouda, T.; Prevost, K.; Gustave, B.; Joseph, D.A.; Nathalie, G.; Raphaël, O.; Rubens, D.; Claude, C.J.; Mireille, D.; Felix, T. Terpenes, Antibacterial and Modulatory Antibiotic Activity of Essential Oils from Croton hirtus L' Hér. (Euphorbiaceae) from Ivory Coast. J. Essent. Oil Bear. Plants 2014, 17, 607-616. [CrossRef]

3. De Lima, S.G.; Medeiros, L.B.P.; Cunha, C.N.L.C.; da Silva, D.; de Andrade, N.C.; Neto, J.M.M.; Lopes, J.A.D.; Steffen, R.A.; Araújo, B.Q.; Reis, F.d.A.M. Chemical composition of essential oils of Croton hirtus L'Her from Piauí (Brazil). J. Essent. Oil Res. 2012, 24, 371-376. [CrossRef]

4. Rosandy, A.R.; Azman, A.A.; Khalid, R.; Othaman, R.; Lazim, A.M.; Choudary, I.M.; Syah, Y.M.; Latip, J.; Said, I.M.; Bakar, M.A. Isolation of New Rotundone from the Roots of Croton Hirtus (Euphorbiaceae). Malays. J. Anal. Sci. 2019, $23,677-681$.

5. Subin, M.; Reghu, N. Phytochemical screening and antibacterial properties of Croton hirtus L'Her. plant against some important pathogenic bacteria. Nat. Environ. Pollut. Technol. 2012, 11, 59-64.

6. Ezeabara, C.A.; Okonkwo, E. Comparison of phytochemical and proximate components of leaf, stem and root of Croton hirtus L'Herit and Croton lobatus Linn. J. Med. Health Res. 2016, 24, 33.

7. Kim, M.J.; Kim, J.G.; Sydara, K.M.; Lee, S.W.; Jung, S.K. Croton hirtus L'Hér Extract Prevents Inflammation in RAW264. 7 Macrophages Via Inhibition of NF-кB Signaling Pathway. J. Microbiol. Biotechnol. 2020, 30, 490-496. [CrossRef]

8. Morreel, K.; Saeys, Y.; Dima, O.; Lu, F.; Van de Peer, Y.; Vanholme, R.; Ralph, J.; Vanholme, B.; Boerjan, W. Systematic Structural Characterization of Metabolites in Arabidopsis via Candidate Substrate-Product Pair Networks. Plant Cell 2014, 26, 929. [CrossRef] [PubMed]

9. Chen, H.-J.; Inbaraj, B.S.; Chen, B.-H. Determination of phenolic acids and flavonoids in Taraxacum formosanum Kitam by liquid chromatography-tandem mass spectrometry coupled with a post-column derivatization technique. Int. J. Mol. Sci. 2012, 13, 260-285. [CrossRef] [PubMed]

10. Bystrom, L.M.; Lewis, B.A.; Brown, D.L.; Rodriguez, E.; Obendorf, R.L. Characterisation of phenolics by LC-UV/Vis, LC-MS/MS and sugars by GC in Melicoccus bijugatus Jacq. 'Montgomery' fruits. In Food Chem.; 2008; Volume 111, pp. 1017-1024.

11. Kamel, M.S.; Mohamed, K.M.; Hassanean, H.A.; Ohtani, K.; Kasai, R.; Yamasaki, K. Iridoid and megastigmane glycosides from Phlomis aurea. Phytochemistry 2000, 55, 353-357. [CrossRef]

12. Kawakami, S.; Matsunami, K.; Otsuka, H.; Shinzato, T.; Takeda, Y. Crotonionosides A-G: Megastigmane glycosides from leaves of Croton cascarilloides Räuschel. Phytochemistry 2011, 72, 147-153. [CrossRef] [PubMed]

13. Anh, N.Q.; Yen, T.T.; Hang, N.T.; Anh, D.H.; Viet, P.H.; Van Doan, V.; Van Kiem, P. 1H-Indole-3-acetonitrile glycoside, phenolic and other compounds from Stixis suaveolens. Vietnam J. Chem. 2019, 57, 558-561. [CrossRef]

14. Fabre, N.; Rustan, I.; de Hoffmann, E.; Quetin-Leclercq, J. Determination of flavone, flavonol, and flavanone aglycones by negative ion liquid chromatography electrospray ion trap mass spectrometry. J. Am. Soc. Mass Spectrom. 2001, 12, 707-715. [CrossRef]

15. Kachlicki, P.; Piasecka, A.; Stobiecki, M.; Marczak, Ł. Structural characterization of flavonoid glycoconjugates and their derivatives with mass spectrometric techniques. Molecules 2016, 21, 1494. [CrossRef]

16. Yang, W.Z.; Qiao, X.; Bo, T.; Wang, Q.; Guo, D.A.; Ye, M. Low energy induced homolytic fragmentation of flavonol 3-O-glycosides by negative electrospray ionization tandem mass spectrometry. Rapid Commun. Mass Spectrom. 2014, 28, 385-395. [CrossRef] 
17. Georgiev, M.I.; Ali, K.; Alipieva, K.; Verpoorte, R.; Choi, Y.H. Metabolic differentiations and classification of Verbascum species by NMR-based metabolomics. Phytochemistry 2011, 72, 2045-2051. [CrossRef] [PubMed]

18. Abarca-Vargas, R.; Peña Malacara, C.F.; Petricevich, V.L. Characterization of Chemical Compounds with Antioxidant and Cytotoxic Activities in Bougainvillea x buttiana Holttum and Standl, (var. Rose) Extracts. Antioxidants 2016, 5, 45. [CrossRef] [PubMed]

19. Rocchetti, G.; Pagnossa, J.P.; Blasi, F.; Cossignani, L.; Hilsdorf Piccoli, R.; Zengin, G.; Montesano, D.; Cocconcelli, P.S.; Lucini, L. Phenolic profiling and in vitro bioactivity of Moringa oleifera leaves as affected by different extraction solvents. Food Res. Int. 2020, 127, 108712. [CrossRef]

20. Pizzino, G.; Irrera, N.; Cucinotta, M.; Pallio, G.; Mannino, F.; Arcoraci, V.; Squadrito, F.; Altavilla, D.; Bitto, A. Oxidative stress: Harms and benefits for human health. Oxid. Med. Cell. Longev. 2017, 2017. [CrossRef]

21. Tan, B.L.; Norhaizan, M.E.; Liew, W.-P.-P.; Sulaiman Rahman, H. Antioxidant and Oxidative Stress: A Mutual Interplay in Age-Related Diseases. Front. Pharmacol. 2018, 9, 1162. [CrossRef]

22. Altemimi, A.; Lakhssassi, N.; Baharlouei, A.; Watson, D.G.; Lightfoot, D.A. Phytochemicals: Extraction, Isolation, and Identification of Bioactive Compounds from Plant Extracts. Plants 2017, 6, 42. [CrossRef] [PubMed]

23. Nardi, G.M.; Felippi, R.; DalBó, S.; Siqueira-Junior, J.M.; Arruda, D.C.; Delle Monache, F.; Timbola, A.K.; Pizzolatti, M.G.; Ckless, K.; Ribeiro-do-Valle, R.M. Anti-inflammatory and antioxidant effects of Croton celtidifolius bark. Phytomedicine 2003, 10, 176-184. [CrossRef]

24. Lopes, M.I.L.e.; Saffi, J.; Echeverrigaray, S.; Henriques, J.A.P.; Salvador, M. Mutagenic and antioxidant activities of Croton lechleri sap in biological systems. J. Ethnopharmacol. 2004, 95, 437-445. [CrossRef] [PubMed]

25. Aderogba, M.A.; McGaw, L.J.; Bezabih, M.; Abegaz, B.M. Isolation and characterisation of novel antioxidant constituents of Croton zambesicus leaf extract. Nat. Prod. Res. 2011, 25, 1224-1233. [CrossRef]

26. Azevedo, M.M.B.; Chaves, F.C.M.; Almeida, C.A.; Bizzo, H.R.; Duarte, R.S.; Campos-Takaki, G.M.; Alviano, C.S.; Alviano, D.S Antioxidant and Antimicrobial Activities of 7-Hydroxy-calamenene-Rich Essential Oils from Croton cajucara Benth. Molecules 2013, 18, 1128-1137. [CrossRef]

27. Bouasla, I.; Hamel, T.; Barour, C.; Bouasla, A.; Hachouf, M.; Bouguerra, O.M.; Messarah, M. Evaluation of solvent influence on phytochemical content and antioxidant activities of two Algerian endemic taxa: Stachys marrubiifolia Viv. and Lamium flexuosum Ten. (Lamiaceae). Eur. J. Integr. Med. 2021, 42, 101267. [CrossRef]

28. Amalraj, S.; Mariyammal, V.; Murugan, R.; Gurav, S.S.; Krupa, J.; Ayyanar, M. Comparative evaluation on chemical composition, in vitro antioxidant, antidiabetic and antibacterial activities of various solvent extracts of Dregea volubilis leaves. S. Afr. J. Bot. 2021, 138, 115-123. [CrossRef]

29. Yoshida, Y.; Niki, E. Antioxidant effects of phytosterol and its components. J. Nutr. Sci. Vitaminol. 2003, 49, 277-280. [CrossRef] [PubMed]

30. Hsu, C.-C.; Kuo, H.-C.; Huang, K.-E. The Effects of Phytosterols Extracted from Diascorea alata on the Antioxidant Activity, Plasma Lipids, and Hematological Profiles in Taiwanese Menopausal Women. Nutrients 2017, 9, 1320. [CrossRef] [PubMed]

31. Richard, D.; Kefi, K.; Barbe, U.; Bausero, P.; Visioli, F. Polyunsaturated fatty acids as antioxidants. Pharmacol. Res. 2008, 57, 451-455. [CrossRef] [PubMed]

32. Goncalves, S.; Romano, A. Inhibitory Properties of Phenolic Compounds Against Enzymes Linked with Human Diseases; IntechOpen: London, UK, 2017.

33. Ramsay, R.R.; Tipton, K.F. Assessment of enzyme inhibition: A review with examples from the development of monoamine oxidase and cholinesterase inhibitory drugs. Molecules 2017, 22, 1192. [CrossRef]

34. Vinholes, J.; Silva, B.M.; Silva, L.R. Hydroxycinnamic acids (HCAS): Structure, biological properties and health effects. Adv. Med. Biol. 2015, 88, 105-130.

35. Szwajgier, D.; Borowiec, K. Phenolic acids from malt are efficient acetylcholinesterase and butyrylcholinesterase inhibitors. J. Inst. Brew. 2012, 118, 40-48. [CrossRef]

36. Khan, H.; Marya; Amin, S.; Kamal, M.A.; Patel, S. Flavonoids as acetylcholinesterase inhibitors: Current therapeutic standing and future prospects. Biomed. Pharmacother. 2018, 101, 860-870. [CrossRef] [PubMed]

37. Szwajgier, D.; Borowiec, K.; Zapp, J. Activity-guided isolation of cholinesterase inhibitors quercetin, rutin and kaempferol from Prunus persica fruit. Z. Nat. C 2020, 75, 87-96. [CrossRef]

38. Ali, M.; Muhammad, S.; Shah, M.R.; Khan, A.; Rashid, U.; Farooq, U.; Ullah, F.; Sadiq, A.; Ayaz, M.; Ali, M. Neurologically potent molecules from Crataegus oxyacantha; isolation, anticholinesterase inhibition, and molecular docking. Front. Pharmacol. 2017, 8, 327. [CrossRef] [PubMed]

39. Oboh, G.; Ademosun, A.O.; Ayeni, P.O.; Omojokun, O.S.; Bello, F. Comparative effect of quercetin and rutin on $\alpha$-amylase, $\alpha$-glucosidase, and some pro-oxidant-induced lipid peroxidation in rat pancreas. Comp. Clin. Path. 2015, 24, 1103-1110. [CrossRef]

40. Taira, J.; Tsuchida, E.; Uehara, M.; Ohhama, N.; Ohmine, W.; Ogi, T. The leaf extract of Mallotus japonicus and its major active constituent, rutin, suppressed on melanin production in murine B16F1 melanoma. Asian Pac. J. Trop. Biomed. 2015, 5, 819-823. [CrossRef]

41. Park, K.-Y.; Kim, J. Synthesis and biological evaluation of the anti-melanogenesis effect of coumaric and caffeic acid-conjugated peptides in human melanocytes. Front. Pharmacol. 2020, 11, 922. [CrossRef] 
42. Truong, X.T.; Park, S.-H.; Lee, Y.-G.; Jeong, H.Y.; Moon, J.-H.; Jeon, T.-I. Protocatechuic acid from pear inhibits melanogenesis in melanoma cells. Int. J. Mol. Sci. 2017, 18, 1809. [CrossRef]

43. Shahwar, D.; Ahmad, N.; Yasmeen, A.; Khan, M.A.; Ullah, S.; Atta-ur, R. Bioactive constituents from Croton sparsiflorus Morong. Nat. Prod. Res. 2015, 29, 274-276. [CrossRef]

44. Keerthana, G.; Kalaivani, M.; Sumathy, A. In-vitro alpha amylase inhibitory and anti-oxidant activities of ethanolic leaf extract of Croton bonplandianum. Asian J. Pharm. Clin. Res. 2013, 6, 32-36.

45. Morocho, V.; Sarango, D.; Cruz-Erazo, C.; Cumbicus, N.; Cartuche, L.; Suárez, A.I. Chemical Constituents of Croton thurifer Kunth as $\alpha$-Glucosidase Inhibitors. Chemistry 2020, 19, 20. [CrossRef]

46. Zengin, G.; Aktumsek, A. Investigation of antioxidant potentials of solvent extracts from different anatomical parts of Asphodeline anatolica E. Tuzlaci: An endemic plant to Turkey. Afr. J. Tradit. Complement. Altern. Med. 2014, 11, 481-488. [CrossRef] [PubMed]

47. Sut, S.; Pavela, R.; Kolarčik, V.; Lupidi, G.; Maggi, F.; Dall'Acqua, S.; Benelli, G. Isobutyrylshikonin and isovalerylshikonin from the roots of Onosma visianii inhibit larval growth of the tobacco cutworm Spodoptera littoralis. Ind. Crops Prod. 2017, 109, 266-273. [CrossRef]

48. Sharan Shrestha, S.; Sut, S.; Ferrarese, I.; Barbon Di Marco, S.; Zengin, G.; De Franco, M.; Pant, D.R.; Mahomoodally, M.F.; Ferri, N.; Biancorosso, N. Himalayan Nettle Girardinia diversifolia as a Candidate Ingredient for Pharmaceutical and Nutraceutical Applications-Phytochemical Analysis and In Vitro Bioassays. Molecules 2020, 25, 1563. [CrossRef]

49. Grochowski, D.M.; Uysal, S.; Aktumsek, A.; Granica, S.; Zengin, G.; Ceylan, R.; Locatelli, M.; Tomczyk, M. In vitro enzyme inhibitory properties, antioxidant activities, and phytochemical profile of Potentilla thuringiaca. Phytochem. Lett. 2017, 20, 365-372. [CrossRef] 